\title{
Reflections on the law applicable to international oil contracts
} Carmen Otero García-Castrillón*

\begin{abstract}
Business activity in the hydrocarbon sector, involving the extraction of natural resources essential to maintain our modern lifestyle, begins with the negotiation of oil and gas exploration and exploitation contracts. Apart from the traditional role of the parties' contractual autonomy, determining the legal regime of these contracts necessitates considering the role of international law, the development of oil sector-specific international rules (lex petrolea), and the impact of the imperative norms of national legal systems, especially in expropriation cases and in those situations in which investments or commercial transactions in a particular State are subject to limits or prohibitions relating to economic coercion measures.
\end{abstract}

\section{Introduction}

When international legal relationships specifically call for the interaction of legal disciplines, which are themselves suffering from what could be described as a 'crisis of definition', 'it can lead to problems. The following analysis of the legal regime behind hydrocarbon contracts (oil and gas) provides an opportunity to highlight these difficulties, as well as a way to deal with them in practice. It will be shown that the usual private international law (IL) approach adopted cannot ignore the public international law (PIL) implications involved in these contracts. ${ }^{2}$ Similarly, both disciplines try to preserve the

* Tenured Professor of Private International Law, Complutense University, Madrid (Spain) and associate member of the Aberdeen Centre for Private International Law. Email: cocastri@der.ucm.es. I would like to thank Prof SA Sánchez Lorenzo and Dr A Rigo Sureda for their comments on previous versions of this paper, for which I am responsible. I am also grateful to Jayne Holliday for the English review.

1 On this issue, A Lowenfeld, 'Public Law in the International Arena: Conflict of Laws, International Law, and Some Suggestions for Their Interaction' (1979-II) R des C 322, 428, had already stressed that interdisciplinarity purports to overcoming fears and stimulating mutual learning among the various branches of Law; particularly, between public and private international law, for which he showed an inclination towards a theoretical option for a unified field. In more recent debates see, among others, the contributions to C Joerges and EU Petersmann (eds), Constitutionalism, Multilevel Governance and Social Regulation, Studies in Transnational Economic Law, vol. 9 (Hart Publishing 2006); and to R Nickel (ed), Conflicts of Laws and Laws of Conflict in Europe and Beyond, Patterns of Supranational and Transnational Juridification (Intersentia 2010).

2 As I Brownlie, Principles of Public International Law, vol. 11 (7th edn, OUP 2008) 549, puts it:

\footnotetext{
... when a claim for breach of a contract between an alien and a government arises, the issue will be decided in accordance with the applicable system of municipal law designated by the rules of private international law. Further questions are raised if parties to a state contract expressly choose an applicable law other than a particular system of local law, either 'general principles of law' or 'public international law'.
} 
public interest, being forced to confront the tension between the differing views on how to define its content and what it could encompass. ${ }^{3}$ However, without avoiding or excluding the need to make all the necessary legal adjustments to the evolving socio-economic environment, it is necessary to recognize that responding to present legal issues requires resorting to present legal frameworks and tools. The following analysis aims to do this.

Hydrocarbon business activities are divided into two main sectors. Upstream activities comprise exploration and production, and conclude with sales transactions (crude oil or gas). Downstream activities include refining and petrochemical production. It is also possible to identify an intermediate phase (midstream) referring to crude oil and gas transportation, that takes place through pipelines or in ships. All of these operations are legally framed by contracts. Due to the location of the resources (hydrocarbons on the one hand and infrastructure and economic and human capital on the other) and the global nature of the demand, these contracts are usually international.

PIL, ${ }^{4}$ as in most national legal systems, ${ }^{5}$ recognizes the public ownership of natural resources. To profit from these resources requires high levels of investment that cannot be assumed exclusively by States or public companies where the resources are located. Therefore, they resort to private companies, usually foreign, ${ }^{6}$ that often create joint

In this regard, A Mann, 'A Theoretical Investigation of the Applicable Law of Contracts Between State and Private Persons' Revue Belge de Droit International (1975) 564-65 stated:

(U)nder normal circumstances, state contracts are governed by the laws of the particular country, although there is another formula suggested a few years ago. According to this formula, the contracts between a state and foreign private persons can be internationalized, that is, putting contracts under another legal system i-e. public international law. It does not mean that state contracts shall be governed by public international law in the same way as treaties or other transactions between countries. What we are saying is that a party to state contracts can choose public international law as the governing law.

3 As D McBarnet, 'Transnational Transactions: Legal Work, Cross-border Commerce and Global Regulation' in M Likosky (ed), Transnational Legal Process (Butterworths 2002) 100-1, puts it, collective action is a solution at the level of shared structures (macro level) while individual action is pursued in particular circumstances (micro level). In this regard, it could be added that the notion of 'subsidiarity', and distinctions between 'Directives' or 'Framework Laws' and Regulations or Laws as the means for putting subsidiarity into practice, could be very useful.

4 A number of UN General Assembly Resolutions-permanent sovereignty over natural resources, 1803 (XVII), right to exploit freely natural wealth and resources, 626 (VII), concerted action in favour of economic development, 15 (XV), and Charter of States' economic rights and duties, 3281 (XXIX) — have established that States have a sovereign and permanent right that has to be exercised in favour of national development and people's welfare to freely dispose, conforming to their interests, of their natural wealth and resources. Academics and arbiters consider the content of these Resolutions as an international custom. $\mathrm{Z} \mathrm{Al}$ Qurashi, International Oil and Gas Arbitration. OGEL Special Study, vol. III (January 2005) 7. It is necessary to clarify that, though coastal States rights on the resources located in the continental platform are not property rights, they comprise the right to explore and exploit them (they can be said to be functional rights).

5 With the exception of the United States and South Africa, whose legislations adopt the traditional common law accession system for resources on shore. Hence, the owner of the land is also the proprietary owner of the subjacent minerals. After the prospects for exploiting shale gas were opened in the last two years and as a result of this property regime, local farmers in Ohio recently leased oil and gas drilling rights on their lands which years ago would have been sold for US\$15 per acre, but is now worth from US\$3.500 to US\$4000 per acre. E Crooks, 'US Shale Gas Bonanza: New Wells to Drag On', FT, 5 October 2011.

6 A number of criteria have been retained in order to determine the foreign character of an investment (for the notion of investment see notes nn 12,13 and 14 below). Some have focused on the investment as a juridical act whilst others enshrine the nationality of the natural or juridical person making it. Art. 1.7 of the Energy Charter Treaty and its Protocol on Energy Efficiency and related environmental aspects (ECT), adopted in Lisbon 17 December 1994, DO (1997), — - organized in accordance with the laws of a ECT Member-, - , and the bilateral investment treaties (BITs), see infra note $n 35$ below, opt for the nationality criteria. In certain cases, it is also established that, when the investment is made by a juridical person, the fact that it is controlled by member States nationals is enough to consider it a foreign investment within the coverage of the treaty (for example,eg art. 1.a of Ecuador--USA 
ventures among themselves to bear the costs of particular projects. Hence, a commercial relationship in the hydrocarbon exploration and exploitation business is frequently established between one or various foreign companies and the State or a public company, which is in one way or another controlled by the State. There are no doubts about the contractual nature of this relationship. ${ }^{7}$ Therefore, questioning the public-administrative or private character - an issue to be resolved according to the applicable law-could be considered irrelevant since these contracts belong to a purely international category where this classical distinction in national law has almost no place or, at the very least, lacks the same meaning. The existence of a State party could make IL a starting point for the characterization of the business and, it is important to note that, IL makes no distinction between administrative contracts and other contracts. However, the administrative or private character of hydrocarbon contracts is by no means a settled issue, ${ }^{8}$ the consequences of which can be seen in certain areas of arbitration practice. ${ }^{9}$ Leaving aside this debate, what is relevant here is simply this: which legal regime will govern the legal relationship? In this regard, it cannot be forgotten that the characterization of these legal

BIT, 27 August 1993). Anyhow, this issue tends to be controversial. For a recent case see Perenco Ecuador Ltd. v. Ecuador and Petroecuador, (ICSID Case No. ARB/08/6), decision on jurisdiction, 30 June 2011, where it is recognized (paragraph para 73) that a company national of the respondent State can bring an action under ICSID Treaty if it is controlled by foreigners (the majority of the shares) for parties to agree that a national of a State that ordinarily could not bring an international claim against its own State would be granted standing under the Convention. A different issue is so-called treaty-shopping which takes places when companies whose contracts do not enjoy the coverage of a BIT, look for it by changing their nationality-being inserted in a holding company subject to the law of a State that has a BIT with the host State, or by moving their seat to this State. Mobil Corporation v. Venezuela, ICSID Case No. ARB07/27, jurisdiction award, 10 June 2010, established (paragraphs paras 204 and 205) that restructuring the investments in order to have them protected is legitimate in respect of disputes taking place after the restructure. This is also the case in ECT arbitration, vid. Yukos Universal Ltd. v. Russian Federation; interim Award on Jurisdiction and Admissibility, PCA Case No. AA227, 30 November 2009. On this issue see, P.M. Blyschak, "'Access and Advantage Expanded: Mobil Corporation v. Venezuela and Other Recent Arbitration Awards on Treaty Shopping"', 4 JWELB 1 (2011) at 32--39.

7 This was established in the three Libyan arbitrations awards: British Petroleum Company (Libya) Limited $v$ Government of the Libyan Arabic Republic, 10 October 1973 (1979) 53 ILR 297 (BP), particularly at 327, para 2-the arbiter so established without studying the issue in depth-; Libyan American Oil Company v Government of the Libyan Arab Republic, 12 April 1977 (1981) 20 ILM 1 (LIAMCO), particularly at 85, and Texaco Overseas Petroleum Company/California Asiatic Oil Company and the Government of the Libyan Arabic Republic, (TOPCO), 19 January de 1977 (1979) 53 ILR 438-41. In the last two awards, the analysis of this issue is more thorough and resort to Mann's reflection stating that 'from an international point of view, a concession is always a contract'. See also JF Lalive, 'Contrats entre États ou enterprises étatiques et personnes privées; developements récents', R. des C. vol. 181, 1983-III, 99 and 124-26.

8 Following Turpin, 'Contracts' 7 (1982) International Encyclopedia of Comparative Law 5; AS El-Kosheri and TF Riead, 'The Law Governing a New Generation of Petroleum Agreements' 1 (1986) ICSID Review 2 at 262-63, talk about the development of a general concept of public contracts whose features are that 'the private contractor becomes indirectly a participant in the performance of a broadly defined public law venture and that he is, on the other hand, subject to certain mandatory conditions which provide for special powers of prerogatives of the State'. The debates on the characterization of these contracts is still alive - at least to try to separate them from International Law-, especially when the local party acts through State controlled enterprises that, in the words of P Vareilles-Sommières and A Fekini, 'Les nouveaux contrats internationaux d'exploration et de partage de production pétrolière en Libye' (2008) JDI 1 at 17-19, 'from a psycological perspective... reflect a policy of State separation from the conclusion and adjudication of these kinds of agreements'. Along this line S Lemaire, Les contrats internationaux de l'administration (LGDJ 2005) 80-104, departing from the distinction between contracts signed by the sovereign State (subject of international law) and by the Administration (subject of municipal law), concludes that State contracts are attributable to the national Administrations. As JC Fernández Rozas, 'Los contratos internacionales en el Derecho minero', Approfondimenti sul Diritto Minerario Nazionale e Introduzione al Diritto Minerario Comunitario e Comparato. Atti del $1^{\circ}$ Congreso di Studi di Diritto Minerario, a cura di R. Federici (CEDAM 2001) 162, reminds readers, despite being private contracts, all the preparatory work for the contract and even its adjudication is governed by administrative law.

9 The characterization of a State contract as administrative has consequences in determining jurisdiction of arbitral awards annulment proceedings. Leaving aside the 'psychological reasoning' and focusing on the respect for the lex fori imperative rules, French practice proves (INSERM $v$ Fondation Letten F Saugstad, Tribunal des conflits, 17 May 2010), that though jurisdiction in annulment cases will generally be assigned to civil courts, where the challenge involves reviewing the awards' compliance with forum mandatory administrative rules, the administrative courts would be considered competent. 
relationships as purely contractual does not make the public authority role of one of the contracting parties disappear, since the State, or the public company under its control, is not only the party deciding to enter into the contract and to put it out to tender, usually through a public bidding procedure, but can also claim its revision or even its revocation in response to the existence of a public interest. Therefore, they are not simply contracts in which the State acts as a private party, which although difficult to define, have been called 'State Contracts' or, previously, 'economic development contracts'. ${ }^{10}$

A different issue, not without debate, is whether these contracts can or cannot be characterized as 'investments' under the Energy Charter Treaty (ECT), ${ }^{11}$ or the large number of bilateral investment protection treaties (BITs) ${ }^{12}$ in order to have access to arbitration before the International Center for the Settlement of Investment Disputes (ICSID) or other investment arbitration forums. ${ }^{13}$ Whatever the characterization is, both

10 In words of P Mayer, 'La neutralisation du pouvoir normative de l'Etat en matière de contrats d'Etat' (1986) 113 Journal de Droit International 1 at 14, on the one hand, the participation of the State excludes the private nature of the transaction and, on the other, it cannot be characterized as a public relation either because it is not in the public (administration) sphere. See also J Verhoeven, 'Contrats entre États et ressortissants d'autres États', en Le contrat économique international.VIIes Journés d'Etudes juridiques J. Dabin (Bruylant/Pedone 1975) 150; and M Eslava Rodríguez, Contratos públicos internacionales (Colex 2003) $116-17$.

11 The ECT, above n 6, differing from the ICSID, below n 13, provides an express definition of investment (art 1.6) as 'every kind of asset, owned or controlled directly or indirectly by an Investor'. Moreover, it provides a list of goods included in the concept and adds that it 'refers to any investment associated with an Economic Activity in the Energy Sector'. It may be concluded that in the ECT, the concept of investment is a wide one.

12 See n 35 below. As an example, art 1.1.a of the Venezuela-USA BIT (27 August 1993, in force 11 May 1997) states 'investment' to mean:

every kind of investment in the territory of one Party owned or controlled directly or indirectly by nationals or companies of the other Party, such as equity, debt, and service and investment contracts; and includes: (i) tangible and intangible property, including rights, such as mortgages, lions and pledges; (ii) a company or shares of stock or other interests in a company or interests in the assets thereof; (iii) a claim to money or a claim to performance having economic value, and associated with an investment; (iv) intellectual property which includes, inter alia, rights relating to: literary and artistic works, including sound recordings; inventions in all fields of human endeavor; industrial designs; semiconductor mask works; trade secrets, know-how, and confidential business information; and trademarks, service marks, and trade names; and (v) any right conferred by law or contract, and any license and permits pursuant to law.

Although the majority of the BITs are in favour, not all of them include the State contracts within their material scope of application (ie art 1139.h of NAFTA excludes public contracts from the scope of application of its investment chapter). On the wide coverage of the investment notion regarding oil and gas contracts, see B Hassane, 'Les contrats miniers' in P Kahn and TW Wäelde (eds), New Aspects of International Investment Law (Hague Academy of International Law, Martninus Nijhoff 2007) 247-54.

13 The ICSID Convention, done in Washington on 18 March 1965, does not contain a definition of investment (art 25.1) due to the lack of parties' agreement. In principle, this was not perceived as a problem since parties are required to consent to arbitration. Consent can be founded on a BIT; see eg Murphy Exploration and Production Company Int'l v Ecuador, ICSID Case No ARB/08/4: Ecuadorian government objected ICSID jurisdiction on the basis of its unilateral refusal to accept it in natural resources litigation (art 25.4), as well as on the lack of respect of the BIT's requirement of a six months 'cooling-off period of previous consultations. The arbitral award (15 December 2010) established the lack of jurisdiction on the basis of the last argument (para 157), unanimously holding that the above mentioned unilateral declaration, first, could not have immediate effect, and, second, cannot affect the application of the BIT (para 89). However, arbiter Horacio Griera rendered a dissenting opinion. Despite the unavoidability of certain control on the presence of the objective elements determining the existence of an investment, the issue is not pacific. vid W Ben Hamida, 'Two Nebulous ICSID Features: The Notion of Investment and the Scope of Annulment Control' (2007) 24 J Int Arb 3 at 287-306. Analysing the 16 ICSID Awards that have dealt with the 'existence' of an investment between June 2004 and September 2008, see S Manziaux, 'The Notion of Investment: New Controversies' (2008) 9 JWIT 6. For an analysis of the decisions adopted on this issue from September 2008 to December 2010, see PE Dupont, 'The Notion of ICSID Investment: Ongoing “Confusion” or "Emerging Synthesis"?' (2011) 12 JWIT 2. These analyses conclude that there is a tendency, at least implicit, towards a consistent case law on a few principles regarding the notion of investment in the ICSID framework: (i) a focus on the economic concept of investment, (ii) a disqualification of purported 'investments' limited to cases of manifest abuse of ICSID forum, and, finally, (iii) a refusal to incorporate into the 
investment and pure commercial (contract) disputes require the applicable law to be determined. Although the types of claims in investment and commercial disputes can be closely related, ${ }^{14}$ it has to be acknowledged that, differing from pure commercial (contract) claims, the law applicable to investment claims, beyond the application or consideration of another set of rules, would always encompass the arguably infringed international investment instrument (ECT or $\mathrm{BIT}^{15}$ ).

From a general perspective, it is possible to establish a basic classification of the most frequent types of oil and gas exploration and exploitation contracts. These include:

- licences or concessions;

- authorizations;

- service agreements;

- participation agreements;

- production sharing agreements (PSAs); and, finally

- cooperation agreements and joint operation agreements (JOA).

The last types of agreement are not true exploration and exploitation contracts but association agreements with a view to exploration and exploitation. Service agreements are very similar to participation agreements, but represent an 'intermediate path' between concession and cooperation agreements. The main differences between them rest in the degree of control retained by the States on the development of the work, compensation and the participation that State companies may have. In practice, different types of contract may be used jointly for the exploration and exploitation of an oil or gas field (licence and participation agreement; licence and cooperation agreement; cooperation agreement and participation agreement), generating a web of contracts that reveals the complex character of the parties' relationship.

The contracts tend to have a relatively prolonged duration due to the nature of the activity and the level of investment, from at least five or six years for exploration and between 25 and 30 years for exploitation. It is usually provided that these deadlines may be extended. The duration, together with the diverse public interests of the contracting State, determine the type of contract as well as the way it is entered into and, afterwards, executed. Overall, during the life of the contract, States aim to achieve the completion of

definition of investment extrinsic additional requirements. It may be concluded that in ICISD, the concept of investment is a wide one.

14 BITs usually include contract claims within the scope of the arbitral jurisdiction when related to investments. This is also the conclusion when reading the investment definition of the ECT, $n$ 6. However, not any breach of contract constitutes a breach of an investment treaty. Although the distinction between treaty and contract claims or the framework for assessing the distinction cannot be said to be definitively established in the arbitral practice, each type of claim should be determined under its own applicable law. This does not preclude that, in analysing of an investment claim under the international investment instrument, the prescriptions of the law applicable to the contract are taken into consideration (eg to determine the international law content of the treaty standard). See M Sasson, Substantive Law in Investment Treaty Arbitration; the Unsettled Relationship between International Law and Municipal Law (Kluwer 2010) 153, 164-65, 170-72. Nevertheless, in Rachel S. Grynberg, Stephen M. Grynberg, Miriam Z. Grynberg, and RSM Production Corp v Grenada ICSID Case No ARB/10/6 (10 December 2010), the USA-Grenada BIT claims were rejected after a contract dispute had been fully litigated in a previous arbitration on the basis of collateral stoppel (an established principle of law applicable in international courts and recognized in art 53 of ICSID Convention).

15 See nn 24 and 25. 
capital and human investment that, with the exploitation of the resources and the satisfaction of domestic oil demand, contribute to national sustainable development, including environmental protection, whereas the goal for foreign companies tends to involve the maximization of economic revenues.

The length of such contractual relationships means that changes along the way are inevitable. Apart from the fact that some issues may have not been anticipated in the contract, circumstances may change in such a way that: (i) it becomes very difficult or impossible for one of the parties to comply with its obligations or (ii) national policies can be modified if the evaluation of the public interests evolves in a different way. From this perspective, oil and gas exploration and exploitation contracts are particularly risky for foreign companies which, in order to gain returns on their investment, need a certain degree of juridical stability. Considering that the legal regime governing the contract will determine how to handle potential situations as they arise, the importance of its identification becomes self-evident. This is, of course, without disregarding the presence in the contract of freezing and/or stabilization clauses. Though in certain cases these clauses aim to somehow interfere with the legal regime ${ }^{16}$ of the contract, they cannot escape the fact that, in the end, their interpretation and application will always depend on it.

This article aims to provide a clear picture of the legal regime of oil and gas contracts from a private IL perspective, without disregarding the evolution of the political, economic and even juridical reality in which the life of the contracts takes place. For this purpose, it is considered appropriate to start with the determination of the applicable law; continue with the development and the scope of application of a specific lex mercatoria, the so-called, lex petrolea, and determine the origin and the scope of the applicable imperative norms. In this regard, it is important to note that, from the normative perspective, together with national rules, international norms from different sources (international governmental and non-governmental organizations as much as commercial uses) and character (hard and soft) cannot be forgotten. Moreover, beyond the contractual clauses and legislative diversity in the world today, investment and commercial arbitral practice has to be taken into consideration as the usual means for dealing with litigation in this area.

16 The distinction between them is not always doctrinally clear. Brownlie (n 2) 550-51, defines intangibility clauses as those contained in an agreement between a government and a foreign legal entity by which the government party undertakes neither to annul the agreement not to modify its terms, either by legislation or by administrative measures. Other authors, such as A Faruque, 'Validity and Efficacy of Stabilization Clauses; Legal Protection vs. Functional Value' (2006) 23 J Int Arb 4 at 319-20, only classify as intangibility clauses those impeding the impact of unilateral administrative measures over the contract and consider those that stop the application of new norms as stability clauses stricto sensu. However, it is possible to consider that whilst 'intangibility' freezes the contract, 'stabilization' allows for its accommodation when there is a change of circumstances-hence, the modalities of this clause would include the hardship and the force majeure, but a more accurate manifestation of the contract stabilization would be in any clause that expressly provide for the renegotiation. P Bernardini, 'Stabilization and Adaptation in Oil and Gas Investments' (2008) 1 JWELB at 98-103; L Cotula 'Reconciling Regulatory Stability and Evolution of Environmental Standards in Investment Contracts: Towards a Rethink of Stabilization Clauses' 1 (2008) JWELB 159-65, AFM Maniruzzaman, 'The Pursuit of Stability in International Energy Investment Contracts: A Critical Appraisal of the Emerging Trends' 1 JWELB (2008) at 126-32. H Mann, 'Stabilization in Investment Contracts: Rethinking the Context, Reformulating the Result' ITN, 7 October 2011, http://www.iisd.org/itn/2011/10/07/stabilization-in-investmentcontracts-rethinking-the-context reformulating-the-result/, stresses that the new approach should provide a much more limited interference with the right of States to regulate in the public interest, while maintaining a useful protection for investors. 


\section{Determining the law applicable to oil contracts}

It is possible to affirm that the autonomous will of the contracting parties, which can be expressed at any time, is an acknowledged principle in international and national legal instruments in its material ${ }^{17}$ and conflict of laws ${ }^{18}$ dimensions. The public nature of one of the contracting parties does not interfere with its operation. ${ }^{19}$ This is so established that it is possible to affirm the existence of a universally accepted general principle of law. However, it does not mean that there are no limits to its material application as well as in the conflict of laws dimensions. ${ }^{20}$ The limits of the conflicts' dimension will depend on the conflict of laws rule used by the authority (judicial or arbitral) called to resolve the disputes arising during the life of the contract.

17 As international examples for obligatory norms see, art 42.1 Convention on the Settlement of Investment Disputes between States and Nationals of Other States (ICSID), http://www.wordbank.org/icsid, 'The Tribunal shall decide a dispute in accordance with such rules of law as may be agreed by the parties'; art 6 of the 1980 Vienna Convention on contracts for the international sale of goods <http://www.uncitral.org/uncitral/es/uncitral_texts/sale_goods/1980CISG.html> and, for soft law, art 1 of the 2004 UNIDROIT Principles on international contracts <http://www.unidroit.org/spanish/principles/contracts/ principles2004/blackletter2004.pdf>, and the Principles of European Contract Law (PECL), <http://web.ebs.dk/departments/ law/staff/ol/commission_on_ecl>. Internally, as examples, in Spanish law, art 25 of the Law 30/2007, 30 October, on the contracts of the public sector (LCSP), BOE $\mathrm{n}^{\circ}$ 261, 31 October, incorporating Directive 2004/18 of the European Parliament and the Council, of 31 March, on the coordination of procedures for the award of public works contracts, public supply contracts and public service contracts [2004] OJ L134/114, amended by Directive 2009/81 [2009] OJ L314, recognizes the parties' contracting freedom as long as their pacts are not contrary to the public interest, the legal regime and the principles of good administration.

18 Internationally, among the compulsory norms it is possible to refer to art 54 of the ICSID Additional Facility Rules <https:// icsid.worldbank.org/ICSID/StaticFiles/facility/AFR_English-final.pdf>; and, with the same wording, art 33.1 of the UNCITRAL 1976 Arbitration Rules, <http://www.uncitral.org/en.index.htm>. They state that 'The arbitral tribunal shall apply the law designated by the parties as applicable to the substance of the dispute'. The same text is maintained in art 35.1 of their new 2010 version, applicable to arbitrations concluded after 15 August 2010 — unless the parties have agreed to apply a particular version of the Rules (art 1.2). Equally, art 17.1 of the ICC Arbitration Rules (1997) 36 ILM 1612, states 'The parties shall be free to agree upon the rules of law to be applied by the Arbitral Tribunal to the merits of the dispute'; and the same text is maintained in art 21 of its new version-applicable from 1 January 2012. In these three cases, it is understood that the conflict of law rules are included. In addition, art 1 of IDI Resolution of 11 September 1979 establishes that 'Contracts between a State and a foreign private person shall be subjected to the rules of law chosen by the parties...' In the EU, the rule is established in art 3 of Regulation 593/2008, 17 June, of the European Parliament and the Council, on the law applicable to contractual obligations (Rome I), DO (2008) L 177/6. However, the applicability of this instrument to State contracts is dubious. As M Eslava Rodríguez (n 10) 157, notes referring to its predecessor-Rome Convention, since there is no express mention to these contracts, only in the case that the ECJ interpreted that the characterization of a contract as administrative according to a member State national law has no influence as to its contractual character, State contracts will remain outside its coverage. On the contrary, the Inter-American Convention on the law applicable to international contracts (Mexico, 17 March 1994), expressly includes in its material scope the contracts in which States or public entities are a party; however, it leaves its members the possibility to exclude all or some of them (art 1.3). In any case, there are only two parties-Mexico and Venezuela-to this Convention. At the national level, however, although in some countries the conflict dimension of the parties' autonomous will is not expressly recognized, the possibility of freedom of pacts is legitimated (ie in Spain, art 19.2 de la LCSP ( $n$ 17) establishes the application of its own rules together with its implementing norms to the preparation, adjudication, effects and termination of administrative contracts, and, with supplementary character, the rest of the national administrative norms; so that private law would be applied only in the absence of administrative norms and always, without disregarding the preferential application of specific norms on special administrative contracts; but art 25.1 —see n 27 below—allows the freedom of pacts).

19 P Leboulanger, Les contrats entre États e enterprises étrangères (Economica 1985) 200. The nature of the intervening subjects does not exercise any influence on the issue. The Libyan arbitration awards (n 7) expressly recognize it in the conflicts dimension.

20 Generally, limits of the autonomous will of the parties can be found on the application of the imperative norms and on the public order exception. International arbitration instruments do not expressly refer to limits in any of the dimensions. In the conflict dimension, Rome I Regulation-whose applicability to these contracts is dubious, n 18 - does not permit choosing the lex mercatoria. Although the initial proposal for the adoption of Rome I Regulation intended to introduce this possibility (Green Paper on the conversion of the Rome Convention of 1980 on the law applicable to contractual obligations into a Community instrument and its modernization, COM (2002) 654 final), it was finally not accepted. However, this limit is overcome in practice on the basis of the material dimension of the parties' autonomous will. 
From the sanctity of the parties' autonomous will comes the fact that the contract is the very first element to determine its applicable law. Hence, it is usual that in oil and gas exploration and exploitation contracts, beside the parties' agreement on concrete substantive commitments and rights which may lead to the birth of professional uses and customs, the rules that constitute the law of the contract, lato sensu, are expressly pointed to in a particular contract clause. The function of this law is to complement the aspects directly governed in the terms of the contract, which are usually extremely long and detailed. This function will be accomplished through the interpretation of the contract clauses as well as through the completion of the parties' rights and duties, the determination of their compliance, or of their non-compliance and the consequences or otherwise of non-compliance. The International Law Institute (ILI) has recognized that in State contracts parties tend to choose as contract law: (i) IL, (ii) a national legal system; or (iii) a combination of both; for example, host State national law, IL and the general principles of law. ${ }^{21}$ It is even possible to consider referring to a particular lex mercatoria, the so-called lex petrolea.

Although many lawyers consistently recommend against references to vague rules or sets of rules as the general principles of $\mathrm{law}^{22}$ in order to avoid the difficulties that arbiters and judges may find in trying to identify them, ${ }^{23}$ it is possible to observe that, in practice, there is a tendency towards (i) resorting to IL and (ii) the development of the lex petrolea. Moreover, resorting to IL is reinforced because it is the system that a number of international instruments, particularly in arbitration, require to apply it in any case ${ }^{24}$ or in cases where the parties did not make a choice of law. ${ }^{25}$ For its part, the development of the lex petrolea receives support, not only from the material will of the parties, but also from international norms on arbitration ${ }^{26}$ and from certain national system rules ${ }^{27}$ that lead to its application or, at the least, to take it into consideration. International law and

21 Art 2 of ILI Resolution of 11 September 1979, allows to opt between one or various national laws or the principles common to them; the general principles of Law, the principles applicable in international economic relations, IL or a combination of all these options.

22 The expression has various meanings but, on its stricter notion, is understood as the non-written rules whose generality permits sustaining an important number of normative responses. D Bureau, Les sources informelles du droit dans les relations privées internationales (Paris II 1992) 61. Enhancing the difference between the general principles of law that constitute transnational rules and the lex mercatoria, E Galliard, 'La distintion des principes généraux du droit et des usages du commerce international', in Etudes offertes à Pierre Bellet (Litec 1991) 216-17.

23 W Wengler, 'Les principes genéraux du droit en tant que loi du contrat',(1982) RCDIP no 3, 498.

24 Art 26.6 of the ECT, without mentioning the existence of a parties' choice of the lex contractus, requires to 'decide the issues in dispute in accordance with the Treaty and the applicable rules and principles of International Law'. Similar terms-but adding the application of the host State rules — can be found in a number of BITs, In addition, art V of the Dispute Settlements Declaration of the Iran-US Tribunal, 20 ILM (1981) 230, establishes that all the cases will be decided 'on the basis of respect for law, applying the conflict rules and the commercial law principles and of the International Law in the terms that the Tribunal establish taking into consideration the relevant commercial uses, contract rules and the change of circumstances'.

25 Art 42.1 of ICSID Convention, n 13 above, leads to apply the law of the State that is a party in the dispute and 'the applicable International Law norms'; and art 54 of the ICSID Complementary Mechanism refers to the conflict of laws rules that the tribunal decides to apply and 'the IL rules that the Tribunal consider to be applicable'.

26 Art 33 of the UNCITRAL 1976 Arbitration Rules—art 35.3 in the 2010 version-n 12, establishes that 'In all cases, the arbitral tribunal ... shall take into account the usages of the trade applicable to the transaction'. Similar terms can be found in art 17 of the ICC Arbitration Rules-art 21.2 in the 2010 version, n 12 above, and in art V of the Dispute Settlements Declaration of the Iran-US Tribunal, n 24.

27 In the Spanish case, arts 267.2 - manufacturing contracts—and 277.3—service contracts signed by the Defense Ministry- of the LCS refer to the application of the norms and uses in vigour in international commerce 'without prejudice of what is agreed by the parties'. See n 69 . 
the lex petrolea provide the regulatory neutrality that parties look for, 'de-nationalize' the applicable law and lead towards the construction of a system on the basis of general principles of law, ${ }^{28}$ mostly identified by international arbitration tribunals. However, it cannot be forgotten that, despite the growing importance of the lex mercatoria (and, therefore, the lex petrolea), not every legal system extends to indirectly resorting to its rules through the operation of the conflict of laws norms. ${ }^{29}$ Moreover, the lex mercatoria is a body of rules that, in addition to being difficult to define, ${ }^{30}$ cannot be considered to be complete ${ }^{31}$; which would lead to the need to connect it directly with IL or with a national legal system. ${ }^{32}$

The following example from a Turkmenistan PSA shows a choice of law clause referring to national law, together with IL principles and practice: 'This Agreement shall be governed by, interpreted and construed in accordance with the Law of Turkmenistan and as applicable, the principles of IL and the decisions of international tribunals and international treaties to which Turkmenistan is a party' ${ }^{33}$ The arbitral award in AGIP Brazzaville SA v Congo, also serves to illustrate this point, since the tribunal respected the choice of Congolese law (at that time, French law) complemented by IL principles. ${ }^{34}$

Reference to IL, understood as comprising the general PIL norms and international treaties, ${ }^{35}$ poses theoretical problems because it is a legal system whose application to the relationships between private parties and States can only be done through analogy, without the private party becoming a subject of IL or the contract a source of international obligations of the State. The parties' option for 'contract internationalization' paradoxically leads to its 'privatization' and maybe, as sometimes suggested in the doctrine, to the creation of a new and specific regime for so-called 'State contracts'. ${ }^{36}$ As the situation stands, except when investment treaties are involved, ${ }^{37}$ IL is only applied to State contracts analogically and, in principle, it should not be used unless the parties have

28 RD Bishop, 'International Arbitration of Petroleum Disputes: The Development of a "Lex Petrolea"' (1997) 2 CEPMLP Internet J $3<\mathrm{http}: / /$ www.dundee.ac.uk/cepmlp/journal/html/volume2.html>.

29 On Rome I Regulation (n 18). However, Inter-American Convention on the Law Applicable to International Contracts, n 18 , allows to choose the lex mercatoria (arts 9 and 10 expressly mention the international commercial principles).

30 K Highet, 'The Enigma of the Lex Mercatoria' in TE Carbonneau (ed), Lex Mercatoria and Arbitration: A discussion of the New Law Merchant (rev edn, Kluwer 1998) 133, 141, describes it as the result of the legal attributes disparity among investors, host countries and international lending institutions, which, seeking to meet new demands, requires stretching and bending existing legal principles. What is finally produced is 'something impossible to define' that 'will cover anything more than the very essential rules of reason'.

31 This is the case even when arbiters are called to decide as amiable compositeur or ex aequo et bono. If the lex mercatoria is used for the reasoning of the award, its gaps would have to be covered with the arbiters own discretion.

32 T Begic, Applicable Law in International Investment Disputes (Eleven 2005) 19.

331997 Turkmenistan PSA Model.

34 AGIP Brazzaville SA v Congo [1982] 21 ILM 730, 735, paras 43, 80.

35 Among the international conventions it is important to note the relevance of BITs, that contain a set of imperative or supplementary rules that constitute the juridical framework of international investment contracts (they include States' and investors' obligations) and, from this point of view, they become an essential source of the law applicable to those contracts. The treatment of the foreign investor usually consists on attributing him a juridical status based on equity (non-discrimination and application of a fiscal regime, at the least, equal to the one afforded to the most favoured nation). Leboulanger (n 19) 86-187.

36 P Weil, 'Problèmes relatifs aux contrats passés entre un État et un particulier' (1972-II) $136 R$ des C 189-234, talked about an 'international law of contracts'.

37 See n 35 above. 
expressly so agreed. ${ }^{38}$ Nevertheless, nothing prevents this kind of agreement from being implied, ${ }^{39}$ and certain arbitral awards have recognized this. Some arbitrators have stressed that the international nature of a dispute and the recourse to international arbitration to solve it, imply the choice of IL as the law governing the contract. ${ }^{40}$ Furthermore, the parties' choice to arbitrate their disputes may constitute a sign of their intent to choose IL as the lex contractus, but this should not be an automatic conclusion. ${ }^{41}$ It should be considered as additional data that, together with other data, for example, the parties' behaviour and, of course, with what can be inferred from the text of the contract itself, should be evaluated by the arbitrators to discern with 'reasonable certainty' ${ }^{42}$ the existence of an implied agreement. In any case, the internationalization of the contract could find its limits in the imperative norms and the public order of the forum State's courts, be they those resolving the dispute or those recognizing and enforcing a foreign decision (judicial or arbitral). ${ }^{43}$

If parties do not opt for IL or any of the above combinations, the lex contractus chosen in the oil and gas exploration and exploitation agreements will usually be the law of the host State. In practice, it is possible to find choice of law clauses leading to the application of a neutral legal system. ${ }^{44}$

The so-called energetic nationalism of the past few years can possibly explain the presence in the most recent contracts of choice of law clauses in favour of local law that avoid any express reference to IL. ${ }^{45}$ For example, the present Venezuela model contract establishes that: 'This contract will be governed and interpreted in conformity with the laws of the Republic...', and the Libyan contract states: 'This agreement shall be governed by and interpreted in accordance with the laws and regulations of Great Socialist People's Libyan Arab Jamahiriya including, without limitation, the Petroleum Law'. The logic of choosing the law of the host State resides in the close link that it has with the contract. ${ }^{46}$ This is so much the case that, in the absence of the parties' choice,

38 Leboulanger (n 19) 209-20, 232; Mayer (n 10) 22.

39 The PCIJ Sentence in the Serbian loans case, Serie A, 20/21, at 41-42, para 93, established that, in order to determine the applicable law, the Court could take into consideration the presumptive intentions of the parties. See $<\mathrm{http}$ ://www.worldcourts. com/pcij/eng/decisions/1929.07.12_payment1.htm>.

40 TOPCO (n 7), -in this case the contract had, in addition, a clause choosing international law; Mobil Oil Iran, Inc et al. $v$ Iran (NIOC), arbitral award no 311-74/76/81/150-3, 14 July 1987 (16 Iran-US Cl Trib 3) at 25, para 73, and AMOCO, Int'l Finance Corp. v Iran, 14 July 1987 (15 Irán-US Cl Trib Rep 189) at 220.

41 Begic (n 32) 58 .

42 These are the terms of art 3.1 of Rome I Regulation (n 18).

43 In words of Leboulanger (n 19) 222, the limits are the imperative norms 'of the State' or the 'international public order as it is conceived, basically, in international courts'. In this regard it is important to note, on the one hand, that the applicable municipal imperative rules would have to be identified, and, on the other, that the 'international public order' will be determined by the forum (be it in the context of the resolution of a dispute, judicially or, more commonly, through arbitration; or be it in the context of the recognition or enforcement of a foreign judgment or arbitral award).

44 In JOAs, for example, it is frequent resorting to a neutral legal regime, usually the English law. M Marmursztjen, 'Les clauses de force majeure dans les contrats de l'amont d'une compagnie pétrolière: un étude de cas', RDAI/IBLJ (1998) 7 at 786 . English law was chosen in the contract between Dutch companies, International Holdings BV, Azpetrol Group BV and Azpetrol Oil Services Group BV and the Republic of Azerbaijan, see n 110 below.

45 Whether an implicit choice for the combined presence of IL could be inferred from the rest of the terms and circumstances surrounding the contract is a different issue. In addition, as it has been shown, see nn 24, 25 and 26 above, arbitration instruments-Iran-US, ECT and, usually, BITs-force the consideration of IL or, at the least, its principles, in any case.

46 The Institute Of International Law (IDI) Resolution, 11 September 1979, on 'The Proper Law of the Contract in Agreements Between a State and a Foreign Private Person' <http://www.idi-iil.org/idiE/resolutionsE/1979_ath_01_en.PDF>, establishes that 'Contracts between a State and a foreign private person shall be subjected to the rules of law chosen by the parties or, failing 
some international instruments use this criterion to determine the applicable law. ${ }^{47}$ In this regard, the UNGA Resolution on the permanent sovereignty of a State over its natural resources, though lacking compulsory effect, establishes that in cases where, according to the applicable law, authorizations were provided to implement activities in this area (which is always the case in oil and gas exploration and exploitation contracts), 'the imported capital and the benefits derived from it must be governed by the national law in force in that State; sharing the benefits in the proportions freely agreed by the investor and the reception State'. ${ }^{4}$

When parties do not make use of their autonomous will to establish the law applicable to the contract, its determination will depend on the competent forum. Generally speaking, it is possible to anticipate that, be it an arbitral or a national jurisdictional court, the ordinary response will be to apply host State law and, at the least, take into consideration commercial uses and IL principles. However, arbitral practice proves that, beyond any combination of these regulatory systems, any of them could also be applied in isolation. ${ }^{49}$ Obviously, in principle the host State law has the closest relationship with the contract, which is the widely accepted subsidiary connection, or exception clause, in national and international conflict of laws instruments ${ }^{50}$ and has been expressly recognized in some arbitral awards. ${ }^{51}$ In any case, there is nothing that forcefully compels this conclusion as the traditional view established by the Permanent International Court of Justice in the

such a choice, to the rules of law with which the contract has the closest link' (art 1) and that, 'in the absence of choice by the parties the proper law of the contract shall be derived from indications of the closest connection of the contract' (art 5).

47

Art 42.1 of the ICSID Convention, n 13 above establishes that in the absence of agreement the Tribunal 'shall apply the law of the Contracting State party to the dispute (including its rules on the conflict of laws)', and, as it has been mentioned above, the IL rules that deem to be applicable. BITs also often establish the application of Host State Laws.

48 UNGA Resolution 1803 (XVII), 1 December 1962, para 3.

49 As an example of an exclusive reference to the lex mercatoria, see Deutsche Schachtbau $v$ R'As al-Khaimah National Oil Co (RAKOIL) (1989) XIV YCA 117, paras 17, 18 and 19; (1987) 2 Lloyd's Rep at 246:

Reference either to law of any of the companies, or of such a State and the State on whose territory one or several of these contracts were entered into, may seem inappropriate, for several reasons. The Arbitration Tribunal will refer to what has become common practice in international arbitrations particularly in the field of oil drilling concessions and especially to arbitrations located in Switzerland... The Arbitration Tribunal therefore holds internationally accepted principles of law governing contractual relations to be the proper law applicable to the merits of this case.

As an example of an exclusive reference to host State law see the IV Libyan PSA model (art 21) which reads: 'This agreement shall be governed by and interpreted in accordance with the laws and regulations of Great Socialist People's Libyan Arab Jamahiriya including, without limitation, the Petroleum Law'.

50 Arts 4.2 and 4.3 of Rome I Regulation (n 18) establishes a number of rules depending of the contract object and, for contracts whose object has not been included - as is the case with exploration and exploitation contracts-, in the absence of parties' choice, the applicable law will be the one corresponding to the domicile of the party undertaking the greatest-except if there are connections with another national law. In hydrocarbons' contracts the most characteristic obligation is undertaken by the foreign company. Nevertheless, these contracts will always be most narrowly linked to the State where its activities take place. In similar terms art 9 of the Inter-American Convention (n 18). See also n 18 on the applicability of both instruments to 'administrative' contracts.

51 In a UNCITRAL arbitration, Wintershall AG v Qatar Government, 21 May 1988 (1989) 28 ILM 802, the arbitral tribunal had to use the 'applicable conflict of laws' — which is usually interpreted as the generally accepted conflict of laws rules-and, on the basis of nexus, decided to apply Qatar Laws. 'In the absence of a controlling choice of substantive governing law clause and in consideration of the close links... the exploration and productions sharing agreement... to Qatar, the governing substantive law shall be the law of Qatar...' '. In similar terms, P Cavin, ad hoc arbiter in Shappire International Petroleums v NIOC, award, 15 March 1963 (1967) 35 ILR 170, pointed out 'the arbitrator ... must look for the common intention of the parties and use connecting factors generally used in doctrine and in case law'. Although the connections lead to the application of Iranian law, the arbiter reasoned-in a controversial way-in favour of the application of IL under the basis of the principles of good faith and parties' intent. See n 71 below. 
Serbian loans case of a presumption that a State would assume the application of a legal system which was not its own in regards to the contracts in which it was a party ${ }^{52}$ was abandoned. In addition, as has been noted, various international instruments in arbitration include norms to determine the applicable law in the absence of the parties' choice. These norms, beyond the referral to the 'applicable' conflict of laws norms, those of the host State or the ones that the court consider to be appropriate, or to the direct application of the host State law, establish the use of IL or its principles and the lex mercatoria, be it in a compulsory way with disregard to the parties' autonomy, ${ }^{53}$ or as alternative connecting factors. ${ }^{54}$

\section{Lex petrolea}

Lex mercatoria has progressively gained a significant relevance in the regulation of international contracts. It is important to note that, strictu sensu lex mercatoria is understood as the self-produced professional norms regulating commercial transactions. ${ }^{55}$ Nevertheless, there is nothing to prevent the regulation of a professional commercial transaction incorporating legal norms originating not in a purely business environment but in national or international legal systems. Taken together and leaving aside their origin, these rules could be considered as the lex mercatoria lato sensu, ${ }^{56}$ be it in general or in a particular type of commercial transaction. Stimulated and acknowledged by national and international rules, self-regulation complements the insufficiency of traditional norms and normative procedures, and, eventually, reflects the explicit legislator refusals to regulate in detail what could promptly become obsolete. ${ }^{57}$ Arbitration has widely contributed to the identification, development and consolidation of this set of norms.

The development of a specific lex mercatoria for the oil sector, as in the case of any other sector of professional uses and customs, does not take place in a linear way and, therefore, does not exclude its evolution or changes. It is the result of a number of diverse circumstances surrounding the fact that practices in certain businesses tend to be similar, even when they take place in different international environments. It is possible to identify different sources of what may become rules of this specific lex mercatoria. An important number of contractual clauses are construed using national laws or contracts from the

52 See n 39 above. In words of the Court, para 86, 'Any contract which is not a contract between States in their capacity as subjects of international law is based on the municipal law of some country'. In the particular case, paras 90 and 91, the Serbian law was governing the relationship because 'The loans in question are loans contracted by the State of Serbia under special laws which lay down the conditions relating to them'. ' ... It is a sovereign State which cannot be presumed to have made the substance of its debt and the validity of the obligations accepted by it in respect thereof, subject to any law other than its own'. Paras 92-93 'Nevertheless, Serbia might have desired to make its loans subject to some other law, either generally, or in certain respects: if that were proved, there would seem to be nothing to prevent it. In this case, however, there is no express (or implied) provision to this effect'.

53 See nn 24 and 26 above.

54 See n 26 above.

55 See nn 22 and 30.

56 In this regard, as McBarnet (n 3) 100-1, explains lex mercatoria 'is construed from below; bottom up'.

57 M Tarrés Vives, Normas técnicas y ordenamiento jurídico (Tirant lo Blanch 2003) 172, 253. 
more influential countries as models. ${ }^{58}$ Others come from principles, standards, recommendations or guides elaborated by international organizations or associations that can be general or sector specific. Among the first type, it is possible to distinguish instruments as diverse as, on the one hand, the UNIDROIT Principles on international contracts or the European Principles of Contract Law, and, on the other hand, the UN Code of Conduct for transnational enterprises, the UN Global Compact Initiative. There are also model contracts prepared by different professional associations within the sector such as the International Energy Committee of American Corporate Counsel Association and, especially, the Association of International Petroleum Negotiators. Moreover, it is not strange that, on the one hand, each company, whether public or private, has its own standard contract as well as its particular code of conduct and, on the other, that States have their own contracting procedures and rules. All these initiatives and instruments, to which conditions for public ${ }^{59}$ and private ${ }^{60}$ financing and guidelines for public transparency ${ }^{61}$ could be combined, creating a feedback loop among them in a framework that has been called 'legal pluralism'. ${ }^{62}$

There is no doubt that these rules, principles, recommendations and models for international contracts constitute useful tools for the parties because, at the very least, they can be used as the basis for initiating negotiations. This way, they promote and ease contracting and, through their frequent use, they may acquire the status of professional customs in the field, hence, integrating at least part of what could be called the lex petrolea, as will be explained later.

In addition, it is important to note that these instruments tend to take into consideration the existence and the defence of public interests and objectives, such as national economic and social development, environmental concerns and the protection of human rights, and even recognize certain substantive standards. Therefore, the reliance on their

58 R Shoylekof, 'The United Kindom Oil and Gas Regime', Approfondimenti sul Diritto Minerario Nazionale e Introduzione al Diritto Minerario Comunitario e Comparato. Atti del $1^{\circ}$ Congreso di Studi di Diritto Minerario, a cura di R. Federici (CEDAM 2001) 239. With the objective of saving time and money, in the UK, for example, coordinated under the Programme PILOT (the government and industry joint task force; <http://www.pilottaskforce.co.uk $>$ ) and under the slogan 'Streamlined Commercial Agreements', standard models are created for certain kind of frequently used agreements (confidentiality agreements, license adjudication, a JOA novation, a trust deed novation, etc) that have to be used by all the companies. PILOT has also established the Progressing Partnership Working Group (PPWG) that, counting with industry and government representations, has elaborated a voluntary code of negotiating commercial practices oriented towards cost reduction and promoting good commercial practices.

59 For example, the World Bank Group Environmental, Health, and Safety Guidelines (EHS Guidelines) are technical reference documents with general and industry-specific examples of Good International Industry Practice. These documents are used as a technical source of information during project appraisal activities financed by the World Bank International Finance Corporation (IFC). <http://www.ifc.org/ifcext/sustainability.nsf/Content/EHSGuidelines>.

60 The Equator Principles establish a credit risk management framework for determining, assessing and managing environmental and social risk in project finance transactions. Project finance is often used to fund the development and construction of major infrastructure and industrial projects. The EPs are adopted voluntarily by financial institutions and are applied where total project capital costs exceed US\$10 million. <http://www.equator-principles.com/>.

61 The Extractive Industries Transparency Initiative is a globally developed standard-with the participation of governments, companies and the civil society - that promotes revenue transparency establishing a methodology participating States have to follow <http://eiti.org/>.

62 F Snyder, 'Global Economic Networks and Legal Pluralism' in GA Bernamm, M Hedeger and PL Lindseth (eds), Transatlantic Regulatory Cooperation; Legal Problems and Political Prospects (OUP 2000) 105-7, 113; and 'Governing Globalisation' in M Likosky (ed), Transnational Legal Process (Butterworths 2002) 71-72, 93. The concept of legal pluralism refers to a distinct regime for governing legal economic networks. They are less a structure of multilevel governance than a conjunction of distinctive institutional and normative sites for the production, implementation and sanctioning of rules. 
rules to develop professional uses may offer companies, which are interested in maintaining a good reputation as one of their more important assets in reinforcing their competitive position, a measure of protection against NGO public opinion campaigns. ${ }^{63}$

Those who follow a more traditional doctrine have been very reluctant to accept the applicability of the lex mercatoria to contractual relations between States and private entities. ${ }^{64}$ Nevertheless, even those that consider that a contract cannot be globally ruled by the lex mercatoria, have recognized that State contracts constitute an exception in this respect. ${ }^{65}$

Lex mercatoria is applied directly when it is incorporated or mentioned in contracts, and applicable international treaties ${ }^{66}$ and/or national law systems. ${ }^{67}$ Equally, it is also applied when it can be considered an international (PIL) custom. Moreover, once the seriousness of its origin and foundations has been tested, lex mercatoria will be applied indirectly when it is used to provide with more specificity and content to open ended juridical concepts which are present in the applicable norms; therefore, providing legitimization to legal reasoning, particularly, arbitral awards. ${ }^{68}$ In other words, instructive criteria are identified and established through the arbitral resolution of parties' disputes that, centred in the oil and gas sector, generate the basis for lex petrolea, ${ }^{69}$ discussed above, whose existence was expressly recognized in a 1982 arbitral award: 'A lex petrolea that was in some sort a particular branch of a general universal lex mercatoria' ${ }^{70}$

The first time that this vision was adopted in practice was in Petroleum Development Ltd $v$ Sheik de Abu Dhabi case, an ad hoc arbitration that took place in 1951. The contract did not establish the applicable law and its article 17 only indicated that it would be 'executed in good will' and in a 'spirit of integrity'; and that it would be interpreted in a 'reasonable' way. From these terms, the arbitral court inferred that no national legal system should be applied and that it was necessary to resort to 'the application of principles rooted in the good sense and common practice of the generality of civilised nations

63 T Wälde, 'International Standards: A Professional Challenge for Natural Resources and Energy Lawyers'in E Bastida, T Wälde and J Warden-Fernández (eds), International and Comparative Mineral Law and Policy. Trends and Prospects (Kluwer 2005) 227.

64 Mayer (n 10) 26-27.

65 P Lagarde, 'Approche critique de la lex mercatoria', Le droit des relations économiques internationales, Etudes offertes à B. Goldman (Litec 1982) 139.

66 See nn 24 and 25 above.

67 See $\mathrm{n} 86$ below.

68 Wälde (n 63) 219-20, 223. For him, at 244-47, the most solvent rules are those produced by international organizations-universal or integrated by the most influential countries-specialized in the topic that count with the services of a large number of experts and diplomats during extended periods and that are explicitly formalized in documents widely supported by all the actors. The standards prepared within the UN system controlling the way in which they are elaborated would be in the second place. The third place is for those rules prepared by industry or jurists' professional associations and finally, those elaborated by NGOs. Therefore, '(T)he well established methods of dealing with legal precedent—stare decisis—both in common law and civil law countries will help to distinguish the more relevant and persuasive international standards from the less persuasive ones'.

69 RD Bishop, 'International Arbitration of Petroleum Disputes: The Development of a 'Lex Petrolea' (1997) 2 CEPMLP Internet J $3<$ http://www.dundee.ac.uk/cepmlp/journal/html/volume2.html>. See also TCC Childs, 'Update on Lex Petrolea: The Continuing Development of Customary Law Relating to International Oil and Gas Exploration and Production' (2011) 4 JWELB 214-59.

70 Government of the State of Kuwait v American Independent Oil Co (AMINOIL), Laudo de 24 de mayo de 1982 (1982) 21 ILM 1036, para 155 . 
- a sort of "modern law of nature" ' ${ }^{71}$ The reference to the practice of the generality of civilized nations places the basis of this lex mercatoria in IL that, at the least, has specific rules in what concerns the property of hydrocarbons, ${ }^{72}$ expropriation, changes of circumstances (rebus sic stantibus), sanctity of contracts (pacta sunt servanda) and compliance with obligations of good faith.

In Saudi Arabia $v$ Arabian American Oil Company (ARAMCO) the arbitral tribunal went through more complex reasoning, which can be explained by the resistance, common in those days (1958), to apply PIL in cases where not all the parties were subjects of IL. The point of departure was the idea that applicable law would be determined by the conflict of law rules of the arbitral forum. However, they were non-existent. Therefore, the tribunal considered that, since there are no such rules in general PIL, it should, firstly, respect the express or implied compromises that parties established in the contract, since the parties' autonomous will is a general principle of law, and, if this did not lead to any conclusion, they would decide taking into consideration all the circumstances of the case. This was what they finally had to do, construing the decision that would have been adopted by 'reasonable people'.

In its analysis, the tribunal established that an oil concession could be equated to a 'constitution', that is, to the fundamental norm with which parties have to comply strictly and where the public-subjective rights of the concessionaire (from which he cannot be deprived as long as he complies with its obligations) are established. Since those rights were related to immovable property located in Saudi Arabia, and the contract was not signed by two States (and, therefore not subject to PIL except for issues relating to the sovereignty and States' international responsibility), the tribunal established the decisive character of the lex situs. In addition, considering the international character of the agreement or concession, it was interpreted that the parties' rights and duties should be complemented by resorting to the general principles of law. Finally, concerning the oil transport and sale aspects of the contract, the tribunal resorted to 'the custom and practice prevailing in maritime law and in the international oil business'. ${ }^{73}$

In contrast, in Shappire International Petroleums $v$ NIOC, faced with the absence of the parties' agreement on the law applicable to the contract, the arbitral tribunal started by rejecting the application of the forum conflict rules (Switzerland). ${ }^{74}$ The contract was signed and had to be executed in Iran; hence, the tribunal observed that the applicable law was, in principle, Iranian law. However, the existence of a clause establishing that the contract had to be executed 'in accordance with the good faith and good will principles', led the tribunal to infer the parties' intent to exclude this legal system. This was explained because, given that the concession had a mixed (public/private) character, any other conclusion would have placed Shappire in an unprotected situation in the event of

71 Lord Asquith of Bishopstone's award in case Petroleum Development Ltd v Sheik de Abu Dhabi (1952) 1 ICLQ 2 at 251. The arbiter accepted that certain English Law principles are integrated in it: '.. albeit English municipal law is inapplicable as such, some of its rules are in my view so firmly grounded in reason, as to form part of this broad body of jurisprudence, this 'modern law of nature'.

72 T Wälde and A Page, 'Editorial' (1993) 11 J En \& Nat Res L I.4 at 1.

73 Saudi Arabia v Arabian American Oil Company (ARAMCO), 23 August 1958 (1965) 27 ILR 171-72.

74 See n 51 above. 
legal changes in Iran; which would be contrary to the good will and the good faith clause. Therefore, the tribunal considered that the reference to the contractual good faith prevented resorting to the rigid norms of any national legal system and it was necessary to '... disentangle the rules of positive law, common to civilized nations, such as are formulated in their statutes or are generally recognized in practice. ${ }^{75}$

It could be said that the reasoning behind the development of the contracts' internationalization theory, is nowadays totally obsolete and not used in practice. ${ }^{76}$

In the three Libyan nationalization cases (BP, TOPCO, LIAMCO), each arbiter read the applicable law clause in a different way. The concession established that it was governed by the principles of Libyan law that were common to IL and, in their absence, by the general principles of law, including those applied by international tribunals. Whilst in BP in 1973 the tribunal established that, in the absence of common principles between Libyan law and PIL, the general principles of law would be applied. ${ }^{77}$ In TOPCO (1977), after stating that parties were free to establish the contract applicable law, the tribunal stressed that the applicable law clause referred to Libyan principles, not to norms, and, hence, their application did not exclude the application of IL principles. The tribunal then established that, under the 'new international law concept', contracts between States and private parties could be 'internationalized' subject to PIL. This was the consequence (i) of including the reference to IL and the general principles of law in the contract; (ii) of the resort to international arbitration to solve the disputes and (iii) of the nature of the dispute between two unequal parties - which meant that the private party had international capacity. Finally, the tribunal considered that Libyan law and IL were in conformity with each other and applied both of them. ${ }^{78}$

In LIAMCO (1977) after accepting as a universal, national and IL principle that parties to a mixed public-private contract are free to choose the applicable law, the arbitral tribunal established the initial application of Libyan law (since it characterized Libyan law, together with Islamic law, natural law and equity principles, as principles of this legal regime) and, alternatively, IL principles. However, those Libyan law elements that were contrary to IL principles had to be excluded. Libyan law applies customary rules, as does IL, with equity and respect for the sanctity of property, of contracts, and of acquired rights. In addition, according to IL principles, it also contemplates the prohibition of unjust enrichment and the obligation to compensate for expropriation. ${ }^{79}$ Therefore, both IL and Libyan law principles were applied.

In 1987, the arbitral tribunal in Mobil Oil Iran Inc v Iran Republic Government and NIOC had to apply the conflict of law rules and the principles of commercial and IL as it considered appropriate. The tribunal concluded that the legality of the disputed expropriation had to be analysed from the IL perspective. Moreover, a contractual clause established that the contract had to be interpreted in conformity with Iranian law, and

\footnotetext{
ibid 171-75.

6 Faruque (n 16) 327-29.

BP (n 7) 327-29, para 3.

78 TOPCO (n 7) 461-62, para 51.

79 LIAMCO (n 7) 60-61.
} 
the tribunal applied this clause literally. Hence, Iranian law was used to resolve interpretative issues, but the commercial and international principles were the ones governing the rest of the issues. ${ }^{80}$

In 1989, in the Deutsche Schachtbau und Tiefbohrgesellsachft mbH $v$ RAKOIL case, the arbitral tribunal departed from the former article 13.3 of the ICC rules on conciliation and arbitration establishing that, in default of the parties' agreement, the arbitrator would determine the applicable law on the basis of what he considered to be the most appropriate resolution of conflict of law. After noting the inadequacy of applying any of the national laws of the parties, the tribunal referred to what has become a common practice in arbitration, in particular in the field of oil concessions and, especially, in arbitrations seated in Switzerland (as was the case here): the application of the 'principles of law generally accepted as regulating contractual relationships' ${ }^{81}$

From all of these arbitrations it can be inferred that there is a search for a generally accepted contractual legal regime for relationships between States and foreign companies in the hydrocarbons exploration and exploitation sector. In pursuing a neutral regulation, parties, through contract clauses, and arbitrators through the application and interpretation of contract clauses, have given a considerable role to the 'internationalization' of the underlying legal relationship and, therefore, to the definitive 'privatization' of States' contracts. ${ }^{82}$ As a consequence, it is possible to witness the appearance of a specific international State's contract legal 'regime' that, based on IL principles (general principles of law) and customary (general) IL at times with imperative (ius cogens) character, ${ }^{83}$ brings in the international commercial principles and practices of the oil sector. These principles and practices constitute the specific lex mercatoria (stricto sensu). Overall, the resulting 'regime' could be said to entail a specific lex mercatoria: the lex petrolea.

Moreover, it is important to note that the role of oil and gas practices in the regulation of these contracts has been expressly acknowledged, not only in the contracts themselves, but also in certain national legislations. ${ }^{84}$ As an example of the way in which contracts refer to the application of these practices, this sentence can be found in a number of contract clauses: ' . . shall apply the generally accepted customs and usages of the international petroleum industry.... ${ }^{85}$

80 See $\mathrm{n} 40$ above at 28.

81 See $\mathrm{n} 49$ above.

82 Leboulanger (n 19) 224-225.

83 Brownlie (n 2) 510-11, defines them as rules of customary law that cannot be set aside by treaty or acquiescence but only by the formation of a subsequent customary rule of contrary effect. They include the principle of permanent sovereignty over natural resources. At 534-36, he states that the expropriation compensation rule has received considerable support from State practice and the jurisprudence of international tribunals. Nevertheless, it can have a number of exceptions.

84 Sometimes practices are referred to without any other characterization. However, it is also possible to characterize them as 'the best' of 'good' practices. A different issue is the 'best endeavour' obligations imposed on Contracting Parties regarding environmental protection and energy efficiency by art 19 of ECT. These are general obligations assumed by States as parties to the Treaty. Although they do not provide a cause of action, it is possible to envision a Contracting Party referring to these obligations as a defence, for example, against allegations that actions taken by it with regard to foreign investments breached other provisions of the Treaty.

85 Oman model contract (1981). Other examples can be found in Clause 7.1.5 of 1982 Ecuador Model for Service Contracts in Exploration and Exploitation of Hydrocarbons, which required companies to adopt 'international best practices', and arts 1.1 and 38, 5.5, 8, 13.2.2 and 20.1, of the 2005 Libyan contracts that defines them (art 1.33) as 'those practices, methods, standards and procedures generally accepted and followed by prudent, diligent, skilled and experienced operators in petroleum 
As an example of national law, the Brazilian case can be cited. ${ }^{86}$ It refers to the 'good international practices of the oil industry' to establish the standard of behaviour that the parties will have to satisfy. They are defined as:

the practices and procedures generally used in all the world by the oil industry prudent and diligent operators in similar conditions or circumstances as experienced in one or a number of relevant aspects of the operations, aiming, especially to guarantee: a) preserving the oil and gas resources, which implies the use of methods and processes to maximize obtaining the resources in a sustainable and viable technical and economic way, with the corresponding control of the reserves reduction and minimizing surface losses; b) operational security that imposes using methods and processes that guarantee the security of the works and the prevention of accidents, and c) environmental protection, which determines the adoption of methods and processes that minimize the impact of the operations in the environment.

Summing up, they comprise all the practices that are generally accepted in the sector as good, secure, economic and efficient. From this definition, it is possible to extract the following elements: the practice has to be internationally applied, and it has to be cautious and rational from the perspective of resource preservation, as well as secure and respectful to the environment. ${ }^{87}$ In this regard it is interesting to remember (see paragraph 13) that the sources of what may become practice, constituting the sector specific lex mercatoria, tend to take into consideration the existence and defence of these and others' public interests, and even recognize certain standards.

\section{Imperative norms}

Exploration and exploitation in the hydrocarbon sector are among the most regulated activities within national legal systems due to the variety of public interests that surround them and their essential role for the national economy. This fact explains that the norms are assigned an imperative character.

It is important to note that, despite their proximity, imperative norms have to be distinguished from public policy considerations. Whilst imperative norms form an integral part of the determination of the applicable law process, public policy considerations only enter the scene once that process is over and the designated law conflicts with the legal system in which the final decision will have to develop its effects. In this regard, it is clear that public policy considerations are related to the forum where the decision is taken - if judicially adopted-or recognized and enforced, be it a judicial sentence or an arbitral award. When these public policy considerations are qualified as 'international', it

exploration, development and production operations and which, at the particular time in questions, in the exercise of reasonable judgment and in light of facts then known at the time a decision was made, would be expected to accomplish the desired results and goals'.

86 Art 44 VI Brazilian Oil Law n ${ }^{\circ}$ 9687, 1997. Sixth round concessions contracts (clause 2.2.21).

87 A Santos de Aragao, 'O contrato de concessao de exploraçao de petróleo e gás’ REDAE, n 5, February, March and April, 2006, at 8 . 
is only due to the fact that they come into play in international situations; but not because there is an internationally defined public policy. As a matter of fact, the content of international public policy considerations is defined nationally; which does not exclude-due to the necessary compliance with the State's international obligations-certain international content. There is, however, an ongoing debate on the existence of a so-called 'transnational public policy' or 'truly international public policy', ${ }^{88}$ which, for the time being, does not have (and probably cannot have) a relevant impact in practice. ${ }^{89}$ It has been said that transnational public policy 'would compromise the fundamental rules of nature law, principles of universal justice, ius cogens in PIL and the general principles of morality accepted by what are referred to as "civilized nations" "90 This type of definition creates a great degree of uncertainty. ${ }^{91}$ Anyhow, if this content were to become an international imperative norm, it would be compulsory for any State to respect it, due to international responsibility, be it in its own laws or through the national courts' application of the international public policy exception (when resolving cases or recognizing and enforcing foreign sentences and arbitral awards).

The imperative norms of the host State will be applicable to exploration and exploitation contracts, without disregarding the application of the lex contractus imperative rules; as has been noted, the lex contractus tends to be the same (host State), although combined with the principles of IL and the sector specific lex mercatoria. The host State's imperative rules are mandatory for its national courts and, eventually for a third-country court $^{92}$ or an arbitration tribunal, as an imperative rule of a law closely related to the contract. In this case, if it was not directly applied, it would be, at the least, taken into consideration.

88 On this debate see the report of WM Reisman ('Law, International Public Policy (So-called) and Arbitral Choice in International Commercial Arbitration' at 849-56) and the opinions of C Kessedjian ('Transnational Public Policy' at 857-70) and A Redfern ('Comments on Commercial Arbitration and Transnational Public Policy' at 871-75) in A.J. van den Berg (ed), International Arbitration 2006: Back to Basics? XVIII Congress of the International Council for Commercial Arbitration ICCA 2006 (Kluwer 2007) with the assistance of the Permanent Court of Arbitration. Provided the situation of the debate, the Resolution (7/2000) adopted at the ILA's Conference on Public Policy as a bar to enforcement of international arbitration awards, held in London, could only request the committee to 'continue its study' (but the New Delhi Conference in 2002 did not deal with this issue).

89 A different, though related, and very much debated issue is to what extent arbitration tribunals should avoid getting involved in the evaluation of national public policies. In September 2011, an International Investment Arbitration and Public Policy website was launched to offer an overview of responses by governments to international investment arbitration. <http:// www.iiapp.org/>.

90 ILA Interim Report on Public Policy as a Bar to Enforcement of International Arbitration Awards. London Conference, 2000 at 6-7, citing, among others, professors B Goldmand and P Lalive.

91 M Pryles, 'Reflections on Transnational Public Policy' (2007) 24 J Int Arb 5, 8. This uncertainty goes well beyond what would be desirable, even in cases where differences are subject to ex-aequo et bono or amiable compositeur arbitrations. In this regard, it is important to note that the discretion conferred on those arbitral tribunals is 'confined to ascertaining the contractual rights and obligations of the parties in terms of fairness of rights and obligations, rather than to consider broader transnational policy considerations'.

92 Art 9.3 Rome I Regulation (n 18) states: 'Effect may be given to the overriding mandatory provisions of the law of the country where the obligations arising out of the contract have to be or have been performed, in so far as those overriding mandatory provisions render the performance of the contract unlawful. In considering whether to give effect to those provisions, regard shall be had to their nature and purpose and to the consequences of their application or non-application'. Criticizing this rule restrictive scope as compared to art 7 of the Rome Convention, see S Sánchez Lorenzo, 'Choice of law and overriding mandatory rules in International Contracts after Rome I' (2010) XII YPrIL 91. On its part, art 11 of the Inter-American Convention ( $\mathrm{n} \mathrm{18)}$, is less demanding since it establishes that the forum, at its discretion, will decide whether it is pertinent to apply the imperative rules of a State with which the contract has a close connection. 
Host State imperative rules deal with diverse issues covering the constitution of companies or the establishment of subsidiaries or branches in the national territory; their participation in bidding rounds when they are required; and environmental protection, fiscal rules, market organization, like competition, export regimes, etc. In the last group it is possible that some norms directly or indirectly allow the interference of the State in the contract, even leading to nationalizations or expropriations of foreign companies.

Moreover, some PIL rules with effects in oil and gas contracts have gained imperative character and, taking into consideration the risk of falling under a State's international responsibility (by courts adopting decisions directly or through the recognition and enforcement of arbitral awards), national courts and arbitration tribunals are bound to respect them. In particular, that is the case with the norms relating to property in the natural resources and to the conditions for nationalization and/or expropriation. ${ }^{93}$ In addition, hydrocarbons are a very politically sensitive sector that tends to be included in imperative economic coercion measures (sanctions) that, adopted in an international organization context, such as by the UN, or unilaterally by any particular State, have direct effects in exploration and exploitation contracts.

\section{Direct and indirect expropriation}

Beyond the definitions that can be found in some international arbitrations, ${ }^{94}$ the MIGA, an international instrument created to offer guarantees to investors, provides a definition of expropriation in the following terms (article 11.a.ii):

any legislative action or administrative action or omission attributable to the host government which has the effect of depriving the holder of a guarantee of its ownership or control of, or a substantial benefit from, his investment, with the exception of non-discriminatory measures of general application which governments normally take for the purpose of regulation economic activity in their territories.

Nationalization has been defined as the transfer to the State, as a result of a legislative act and for reasons of public interest, of a property or of private rights with the aim of subjecting them to the State's exploitation or control, or to assign them to a new objective. ${ }^{95}$ In any case, IL treats both institutions in a parallel way. ${ }^{96}$

International law does not prohibit expropriations or nationalizations. Either would constitute the exercise of a sovereign right whose legitimate exercise is, nevertheless, subject to compliance with certain requirements. Beyond being in the text of a number of international hard and soft law instruments, the requirements can be said to have acquired a customary character. Hence, it is necessary to proceed with a public goal, in a non-discriminatory manner and in accordance with a legal procedure. Moreover, the

93 See nn 2 and 83 above.

94 In $A M O C O$ (n 40) 220, it is defined as a 'compulsory transfer or property rights'.

95 Annuaire de l'Institut de Droit International, 1952-II, at 279.

96 In $A M O C O$ (n 40) 220, nationalization is defined, at 222-23, as the 'transfer of an economic activity from the private property to the public sector that is done through the expropriation of a company goods or capital with the aim to maintain them under the State control'. 
State has to compensate the owner of the expropriated property. ${ }^{97}$ Non-compliance with any of these requirements, that would have to be alleged and proved by the prejudiced party, would transform the expropriation to an internationally illicit act (confiscation), raising the State's international responsibility and providing the private party with the right to claim and obtain compensation for damages (determining the appropriate forum for such a claim is another issue).

The imperative character of these international norms and, consequently, their applicability has been recognized in a number of arbitral awards ${ }^{98}$ independently of the fact that parties could have chosen a national law as lex contractus and, in the absence of choice, that the arbitral rules establish the subsidiary application of a national law or/and IL. In AMOCO, the arbitral tribunal distinguished between the law applicable to contract interpretation, Iranian law, chosen by the parties, and the law used to determine the existence of expropriation, which was IL, (including in this case the existence of a Iran-USA bilateral friendship treaty). ${ }^{99}$ This was also the case in the arbitral tribunal in MOBIL. ${ }^{100}$

The progressive sophistication of the measures that restrict property rights or limit their exercise runs parallel to the development, in international arbitration, of the intangible and tangible property distinction, and consequently the differentiation between direct and indirect (also called creeping or regulatory) expropriation. Whilst direct expropriations are easily identifiable, indirect expropriations, also known as de facto takings, present more problems since it can be difficult to set the boundaries between the State's legislative and administrative actions legally limiting the exercise of property rights, and those legislative and administrative actions that do it in an excessive way, leading to an expropriation. In this regard, it should be remembered that IL does not prohibit States from adopting measures affecting property rights where they are within the limits of the public power action, respond to conflictive or emergency situations, and are necessary to preserve life and property or to maintain public order, health or morality. ${ }^{101}$

Direct expropriation implies the compulsory transfer to the State of the property rights of the foreign company. This can be done through nationalization in every economic sector or in a particular one, as in the case of oil and gas, and is articulated in decrees or other legislative measures; hence its identification is easy. Although some authors thought that these actions would not take place again after the changes resulting from the abandonment of the colonial regime and the old concessions, ${ }^{102}$ reality proves that the

${ }^{97}$ This is the line followed by art 13 of the ECT (n 6). In equivalent terms see art IV.2 of the World Bank Guide on the treatment of foreign direct investment, (1992) 31 ILM 1363.

98 I Iruretagoyena Aguirrezabalaga, El arbitraje en los litigios de expropiación de inversiones extranjeras (Bosch 2010).

99 AMOCO (n 40).

100 MOBIL (n 40).

101 In this regard, as A Newcombe puts it, 'The Boundaries of Regulatory Expropriation in International Law' in P Kahn and TW Wälde (eds), New Aspects of International Investment Law (Academy of International Law, Martninus Nijhoff 2007) 392, international expropriation law is not aimed 'to achieve a welfare-maximizing' in the protection of foreign investment but to provide a minimum level of protection from State appropriations and arbitrary conduct. Hence, for higher protection investors 'should use appropriate risk allocation mechanisms such as insurance, contract and diversification'.

102 N Horn, 'Changes in Circumstances and the Revision of Contracts in Some European Laws and International Law' in N Horn (ed), Adaptation and Renegotiation of Contracts in International Trade and Finance. Studies in Transnational Economic Law, vol. 3 (Kluwer 1985) 28-29. It can be reminded that, beyond the 1917 Russian revolution, the first nationalization in the oil industry took place in Mexico in 1938. 
contrary is true. Some experiences in the Americas and Russia show that states nationalize and expropriate.

In May 2006 in Bolivia, a Legislative Decree nationalized the hydrocarbons sector (production and commercialization) alleging, among other things, that the contracts then in force violated the Constitution, which required an express Congress approval for each contract that had never been obtained. ${ }^{103}$ Almost simultaneously, the 2006 Venezuelan hydrocarbons law forced modification of the exploration and exploitation contracts, removing their rights for all the companies that were not ready to reach a new agreement with the administration without express nationalization. A number did not continue operating in the country under the new conditions and requested arbitrations before the ICSID. ENI initiated the process arguing contract non-compliance and expropriation and settled in 2008. ${ }^{104}$ ConocoPhillips and Exxon continued with their claims. ${ }^{105}$ In Russia, it is possible to point to the measures adopted to intervene with Yukos, the oil company, which led the initiation of a number of arbitrations as a result of the expropriation suffered by the foreign partners. ${ }^{106}$ In a more specific way, in Ecuador, a conflict between Petroecuador, a public company, and Occidental Petroleum (USA), ${ }^{107}$ initially intended to revoke their JOA after the (arguably undue) transfer of 40 per cent of Occidental assets to EnCana (Canada) in 2000; but which turned, in spring 2006, into an alleged expropriation of Occidental assets. For its part, Ecuador's government considered it to be a takeover resulting from a contractual breach and law infringement. ${ }^{108}$

103 Supreme Decree 28071, 1 May 2006, of Bolivian oil and gas nationalization. The 1996-97 privatization process was considered an act of national betrayal that gave to foreign hands the control and management of a strategic sector; hurting national sovereignty and dignity. The government threatened companies stating that it would not renegotiate contracts with those companies resorting to arbitration. However, on 12 April 2010 (when the 'cooling-off period for Bolivian withdrawal from ICSID had not yet finished), Pan-American Energy requested arbitration over nationalization of Chaco Petroleum. Bolivian government responded by sending a formal letter to ICSID in protesting the registration of the arbitration request. Pan-American Energy LLC v Plurinational State of Bolivia, ICSID Case No ARB/10/8. The arbitral tribunal is not yet constituted.

104 See ITN, 15 November 2006. Eni Dación BV v República Bolivariana de Venezuela, ICSID Case No ARB/07/4. Agreement adopted on the 18 April 2008.

105 ConocoPhillips $v$ Venezuela, ICSID Case No ARB/07/30, Mobil v Venezuela, ICSID Case No ARB/07/27, and Mobil Cerro Negro v PDVSA and PDVSA Cerro Negro S.A, ICC No 15416/JRF. On the regulatory history of these nationalizations and the perspectives for investments in the area, see J Cárdenas García, 'Rebalancing Oil Contracts in Venezuela' (2011) 33 Huston J Int’l L 235-301.

106 Menatep, who was the majority shareholder, initiated arbitration procedures under ECT against Russia. Russia had signed the ECT but did not ratify it and, in August 2009, notified its intention not to become a member. However, it was compelled to its provisional application (art 45) in respect of investments taking place from the Charter's signature until October 10, 2009. See Yukos Universal Ltd $v$ Russian Federation; Interim Award on Jurisdiction and Admissibility, PCA Case No AA227, 30 November 2009; still pending. Simultaneously, the PCA did also establish its jurisdiction in Veteran Petroleum Trust v Russian Federation; and Hulley Enterprises Ltd $v$ Russian Federation; Interim Awards on Jurisdiction and Admissibility, PCA Case Nos AA226 and AA228, 30 November 2009.

107 The initial dispute, where Occidental alleged an indirect expropriation, was subject to the Ecuador-USA BIT UNCITRAL arbitration, sitting in London. The expropriation claim was dismissed, but the tribunal found a violation of the national and of the fair and equitable treatments (para 200) —see below. Ecuador claimed for the annulment of the award, no 3467, 1 July 2004, before the British courts, that assumed their competence and rejected (2 March 2006). After appeal, the judicial decision was confirmed on 4 July 2007.

108 Once the Minister of Energy declared the expiry of the contract with Occidental, on 15 May 2006, on 17 May Petroecuador seized Occidental goods in 1billion dollars. When initiating the ICSID arbitral process, on 13 July 2006, Occidental demanded the restoration of its rights and that the government could not allow other foreign investor to operate on its installations until the difference was resolved. Occidental Petroleum Corporation and Occidental Exploration and Production Company $v$ Republic of Ecuador, ICSID Case No ARB/06/11. Decision on provisional measures, 17 August 2007 and Decision on jurisdiction, 9 September 2008. The case is still pending. 
The expression 'indirect' or 'de facto' expropriation indicates that the investor's assets were not directly taken, but were subject to measures that have the same effect; that is, the investor is deprived of the right of enjoying its investment therefore there is no need for a transfer of its property title. This expropriation is expressly referred to in the ECT, many BITs and the World Bank Guide when they mention the measures 'with equivalent or similar effect to the nationalization or expropriation'. Obviously, the problem with these expropriations lies in their identification because ordinary national legislative activity can easily interfere in the enjoyment of a property right, and it may be difficult to determine to what extent this interference becomes an expropriation. To determine its existence, it is necessary to analyse case by case, and evaluate the consequences of the normative measures, taking into consideration the expectations of the investor regarding the enjoyment of the investment and that it cannot expect the absolute juridical immobility of the investment in the host State.

Considering the circumstances, the obligatory sale of foreign property, excessive or irrational taxes, ${ }^{109}$ exercising investment management control, or the combination of various measures, can qualify as expropriations. It is not unusual that claims for indirect expropriation are the result, not of an isolated normative action, but of a number of them (process expropriation), ${ }^{110}$ which, in addition to making the analysis more complicated, makes it difficult to determine the moment at which the expropriation took place. ${ }^{111} \mathrm{It}$ should be noted that establishing this precise moment is essential to the effect of calculating the corresponding compensation. All these reasons lead to the conclusion that, more than trying to establish a list of actions that could become an indirect

109 As an illustration, in March 2006 Ecuador decided to charge foreign oil companies a 50 per cent tax on windfall profits. In addition to implying a contract modification, this lead to arbitration requests because the prejudiced parties experience a tax increase that could entail an indirect expropriation. See (with this and additional claims) Burlington Resources Inc. and others $v$ Republic of Ecuador and Petroecuador, ICSID Case No ARB/08/5, Decision on Jurisdiction (2 June 2010). The case is still pending. A similar situation occurred in Chad when, in August 2006, expelled Chevron and Petronas under the accusation of not paying taxes (486 million US dollars). A England, 'Chad Angles for Greater Share of Oil Rewards', FT, 4 September 2006. However, no news about the conflict has been published afterwards. On the expropriation due to tax measures see T Wälde and A Kolo, 'Confiscatory Taxation under Customary International Law and Modern Investment Treaties' (1998) 4 CEPMLP Internet J $17<\mathrm{http}: / /$ www.dundee.ac.uk/cepmlp/journal/html/volume4.html>.

110 As an example, different claims were presented against Argentina alleging indirect expropriation resulting from the emergency measures adopted to face the country's financial crisis. In the oil sector, the ICSID established its competence to resolve the still pending claim presented by TOTAL (France) on the basis of the Argentina-France BIT (ARB 04/1). Azpetrol-and other Dutch companies-initiated an ICSID arbitral procedure against Azerbaijan (ARB 06/15) alleging an indirect expropriation-violating the ECT—as a result of governmental measures adopted after commercially related internal conflicts and political changes took place in the country. However, the case was dismissed for lack of jurisdiction after the arbitral tribunal understood that the parties had reached a binding settlement agreement on 16 December 2008 (8 September 2009, award).

111 In the award in Sedco $v$ Islamic Republic of Iran and National Iranian Oil Company (NIOC), 9 Iran-US Cl Trib Rep at 277, the moment when the expropriation took place was when the designation of temporary directors resulted in the denial to the foreign companies of access to corporate funds and the deprivation of the right to participate in the direction and control of corporative issues. In AMOCO (n 40) para 182 at 244, the arbitral tribunal, after recognizing that the expropriation took place in a process with different stages, dictated that the moment in which it had to be established was the final act. Nevertheless, when it came to determining the date for the evaluation of the expropriated assets and the interest payments, used an earlier date, from which the company was effectively deprived of the property right. In Phillips Petroleum Co Iran v Islamic Republic of Iran, award no 425-39-2, 29 June 1989, 21 Iran-US Cl Trib Rep 115-16, this criteria was adopted to fix the expropriation date: '... whenever events demonstrate that the owner was deprived of fundamental rights of ownership and it appears that this deprivation is not merely ephemeral a taking will be found'. B Kuniy, 'The Notion of Time in ICSID's Case Law on Indirect Expropriation' (2006) 23 J Int Arb 337-49, concludes that arbitral ICSID awards take into consideration the moment when there is a loss of benefits, which can be contrary to IL as well as to the ICSID objectives. 
expropriation, what is important is trying to define the basic elements that permit affirming its existence. ${ }^{112}$

For this purpose, it is useful to reflect on the diverse ways in which the indirect expropriation test is interpreted or applied in the arbitration awards that have dealt with this issue in the hydrocarbons field so far. This began with the Iranian nationalization arbitrations. There are two approaches that can be adopted. The first relies on the specific weight of the governmental measure and on the owner's possibility to enjoy its own property. In other words, it is essentially focused on the governmental intent (sole effects test). The second is centred in the context and the objective that the government pursued with the measure, considering the good faith and the legitimate use of public power in adopting the measure; all of it, without forgetting about the evaluation of the measure's effect on property rights (purpose test). Recent arbitrations in the field tend to rely on this second option, looking for a balance between the care and defence of public and private interests.

Proof of the search for this equilibrium is the arbitral award adopted in the Petrobart case. The Gibraltar company claimed the existence of an indirect expropriation, contrary to the ECT, departing from the non-compliance of the payment obligations established in a gas sale contract with KMG a Kyrgyzstan national company, which had been confirmed by a sentence of the Kyrgyzstan courts. In particular, KMG obtained an authorization to temporarily delay (by three months) of the execution of the sentence and, when the payment time arrived, it was declared insolvent because its assets had been transferred to other public companies. The arbitral tribunal established that the governmental measures, despite having negative effects for Petrobart, were not specifically aimed against the investment and did not have the objective of transferring its assets to the State; hence, they did not constitute an ECT forbidden de facto expropriation. ${ }^{113}$

Although the evaluation of the measures' objectives and their effects have an essentially subjective character, arbitral tribunals embark on analysis that aims at overcoming subjectivity on the basis of facts such as (i) the value diminution as the result of the government's interference; (ii) the weight of the governmental measure, which has to be 'substantial'-understood as the investor's loss of the power to use or to dispose of his property $^{114}$; (iii) the deprivation of benefits that the investor may have suffered; (iv) the loss of his legitimate expectations, reasonably based on the State's obligations; (v) the rights of the parties under the contract of the general legislation and (vi) the proportionality of the State measure to obtain its legitimate public welfare objectives. ${ }^{115}$ Some authors, without leaving aside the proportionality of the measure, argue that what has to

112 Qurashi (n 4) 141.

113 Petrobart Ltd v Republic of Kirgiz, no 126/2003, 29 March 2005, para 8, at 77, <http://www.investmentclaims.com>. Petrobart unsuccessfully questioned the award validity before Swedish courts (it was a Stockholm Chamber of Commerce Arbitration), ITN, 1 February 2007.

114 As an example, in EnCana $v$ República de Ecuador-a London-based arbitration on the basis of the Ecuador-Canada BIT-the award (no 3481, rendered on 3 February 2006 (2006) 45 ILM 4 at 901-61) established that EnCana was not deprived of its rights by the refusal of the government to reimburse the IVA, para 197.

115 LI Fortier and S Drymer, 'Indirect Expropriation in the Law of International Investment: I Know It When I See It or Caveat Investor' (2004) 19 ICSID Rev 300-8. 
be taken into consideration is essentially the existence of the governmental 'appropriation' as a result of the measure. ${ }^{116}$ Therefore, they insist on the 'effects dimension' of the measure, despite its not being highlighted in the arbitral awards. ${ }^{117}$ Summing up, national measures that are legitimate, proportional, and non-discriminatory that do not result in the economic inutility of the property rights, do not constitute indirect expropriations. $^{118}$

The conditions that IL requires for the legality of the direct and indirect expropriations start from the prohibition of discrimination. Discrimination may exist in formal and/or material (effects) terms and the rule demands that, in similar conditions, foreign investors receive the same treatment as nationals. The difficulty in determining the compliance or non-compliance with this requirement resides in establishing the similarity of the conditions found by national and foreign companies, which requires evaluating the circumstances on a case-by-case basis. The burden of proof falls on the contracting party claiming the violation and, eventually, on the party trying to justify the existence of discrimination. The treatment difference would be admissible if it is objectively justified and it is proportional to the end sought. ${ }^{119}$ A totally different issue is the "just and equitable' treatment that States commit to offer investors and that is associated to their legitimate expectations. This is an additional, though related commitment, ${ }^{120}$ which is usually acquired through international treaties, ${ }^{121}$ that provides for compensation to States for acts that do not constitute expropriation. ${ }^{122}$

The public purpose justification of expropriation ${ }^{123}$ has no IL definition. Generally, the public purpose is understood as the national security interest, as much as the well-being of

116 A Newcombe, 'The Boundaries of Regulatory Expropriation in International Law' (2005) 20 ICSID Rev 1-9.

117 Al Qurashi (n 4) 165.

118 TW Waelde and A Kolo, 'Environmental Regulation, Investment Protection and "Regulatory Taking” in International Law' (2001) 50 ICLQ 811-14.

119 In AMINOIL (n 70) 1019, para 87, the arbitral tribunal considered that, differing from AMINOIL, Arabian Oil Company was not nationalized, did not constitute a discrimination because there were adequate reasons to adopt the measure (the production costs of the Arabian Oil Company were larger-offshore production—and, moreover, it was a concession made jointly by Kuwait and Saudi Arabia). Along this line, in AMOCO (n 40) 231, the arbitral tribunal considered that Khemco was not in the same circumstances as the comparative reference company (Iran Japan Petrochemical Company-IJPC) and that, in addition, a nationalization policy could be progressively implemented; so that IJPC — that had not been nationalized before- could be nationalized latter. In BP (n 7) 329, para 4, and in LIAMCO (n 7) 60, arbiters established that the expropriations decided as a political retaliation are discriminatory.

120 That is, the obligation to provide 'effective means of asserting claims and enforcing rights'. This compromise as established in art II.7 of the US-Ecuador BIT-was declared to be infringed in the UNCITRAL Rules arbitration Chevron Corporation (USA) and Texaco Petroleum Company (USA) v The Republic of Ecuador, interim award, 1 December 2008; partial award, 30 March 2010, and final award 31 August 2011.

${ }^{121}$ In addition to the BITs, art 10.1 ECT (n 6), includes this requirement: 'Each Contracting Party shall, in accordance with the provisions of this Treaty, encourage and create stable, equitable, favorable and transparent conditions for investors of other Contracting Parties to make investments in its area. Such conditions shall include a commitment to accord at all times to investments of investors of other contracting parties fair and equitable treatment...'

122 That was the case, for example, in Petrobart case (n 113) para 8, at 76, where the arbitral tribunal considered that the transfer of KGM goods to other public companies, in prejudice of the company's creditors, and the intervention in the judicial procedure to temporally suspend the execution of the sentence, constituted a violation of the just and equitable treatment required by the ECT.

123 Only in LIAMCO (n 7) 58, the sole arbiter did not consider it as a requirement: 'As to the contention that the said measures were politically motivated and not in pursuance of a legitimate public purpose, it is the general opinion in international theory that the public utility principle is not a necessary requisite for the legality of nationalisation... Motives are indifferent to international law, each state being free to judge for itself what it considers necessary for the public good... The objectives pursued by it is of no concern to third parties'. 
the community for genuine social and/or economic reasons that, adopted by the State itself or by its public companies, ${ }^{124}$ supersedes private interests. States have a wide freedom to decide what is in the public interest, but this does not prevent the decision eventually being subject to the scrutiny of an international tribunal, since the expropriation is only justified if it is reasonable and proportionate to achieving its public objective. Hence, different arbitration awards have established that when the only purpose of the expropriation is to avoid complying with the contractual obligations of the State, it cannot be considered a legal action because it would be contrary to the principle of good faith. ${ }^{125}$ In addition, it is generally accepted that one State has no right to expropriate only for financial purposes, ${ }^{126}$ or simply as political retaliation against an act of the State of the foreign company. ${ }^{127}$ The expropriation is only justified if it is necessary, that is, if there is no alternative measure that is equally effective but interferes less with the property.

In reality it will not always be easy to detect whether the public interest justifications for the expropriation are genuine. In Russia in 2006, the government took a number of initiatives to revoke foreign companies' licences arguing environmental reasons that, coinciding with the national policy of reinforcing the energy sector, were seen as purely political actions. ${ }^{128}$ Nevertheless, the administration insisted in explaining that they were real environmental measures that were also applied to Russian companies (without discrimination). ${ }^{129}$

As to compensation in expropriation cases, although some authors maintain that presently the international standard is limited to the compensation being adequate, ${ }^{130}$ the obligation to compensate has to be complied with in a 'prompt, adequate and effective'131

124 AGIP (n 34) 734, para 74: 'if a State, in participating in the formation of the capital of a company, performs an act in the private sphere analogous to the action of an individual, it is nonetheless acting in the general interest of the community for which it is responsible. Thus, the fact that the state that nationalises a company is a shareholder cannot alone warrant the conclusion that this step is not taken in the general interest'.

125 AMINOIL (n 70) 1025, para 109. The reason for the Kuwait nationalization was not to end the contractual relation with AMINOIL but to put into practice a specific governmental plan to regain the full property of its natural resources.

126 AMOCO (n 40) 233. Although they were considered financial objectives, the nationalization responded to the objective one of the economic policy objectives of the new Islamic government in Iran.

127 BP (n 7) 314-18. BP's interests in a Libyan concession had been nationalized arguing that the UK had not intervened to avoid the invasion of certain islands under Libyan control in the Persian Gulf.

128 The prosecutor requested the government to revoque the Rospan - a subsidiary of the Ruso-British company-license due to non-compliance with environmental rules in Siberia. Exxon-Mobil went through something similar in the Sakhalin-1 project and Royal Dutch Shell in the Sakhalin-2 project (whose costs threatened to become much larger than the initially previewed), following a denunciation of the Russian environmental agencies. In Sakhalin-2, just when Gazprom was renegotiating the acquisition of a larger percentage in the Project and its costs were soaring, an environmental permit was cancelled-which may have caused the suspension, and eventually, the cancellation of the exploration and exploitation license. A Ostrovsky, 'Russia Movers Against Rospan Oil Executive', FT, November 2006, 'Probe into Shell Sakhalin-2 is Extended', 26 October 2006, and 'Threat to Sakhalin-2 Shakes Confidence, Warns Beckett', FT, 23 September 2006. Then Royal Dutch Shell offered Gazprom the cession of the project majority control, N Buckley and A Ostrovsly, 'Shell's Hopes for Sakhalin-2 Resolution', FT, 18 December 2006. Finally, On 21 December 2006 OAO Gazprom (Gazprom), Royal Dutch Shell plc (Shell), Mitsui \& Co, Ltd (Mitsui) and Mitsubishi Corporation (Mitsubishi) signed a protocol to bring Gazprom into the Sakhalin Energy Investment Company Ltd. (SEIC) as a leading shareholder, <http://www.shell.com/home/content/media/news_and_media_releases/arch ive/2006/sakhalin_protocol_21122006.html>.

129 N Buckley, 'Russia Threatens to Revoke 19 Lukoil Oilfield Licenses', FT, 16 October 2006 and A Ostrovsky, 'TNK-BP Gas Field Development Faces Suspension', FT, 20 September 2006.

130 I Brownlie separate opinion in the arbitration CME Czech Republic SA v Czech Republic, award from the 13th March 2003, $<$ http://www.cetv-net.com/iFiles/1439-separate-op-pdf-1403.pdf $>$.

131 UNGA Resolutions, nn 135 and 136; ECT (art 11.2) and BITs. In AMINOIL (n 70) 1032-33, paras 143 and 144, the arbiter pointed to the customary character of the rule. 
way. The promptness ${ }^{132}$ and the effectiveness ${ }^{133}$ evaluation, which are understood as part of the adequacy test, do not usually present problems. However, adequacy is often problematic because, despite offering the necessary flexibility to be adapted to each individual case, ${ }^{134}$ it is not clear which criteria have to be used to determine its scope, arguing whether they have to be fixed according to the expropriating State law or to IL. The early UNGA Resolutions, that do not have obligatory character, refer to this issue in the following terms: 'In such cases the owner shall be paid appropriate compensation, in accordance with the rules in force in the State taking such measures in the exercise of its sovereignty and in accordance with international law'. ${ }^{135}$ From 1974, the Resolutions marginalized the reference to IL in this respect. ${ }^{136}$ However, it seems that academic doctrine ${ }^{137}$ and arbitral practice are inclined to search for international rules on this issue.

It cannot be said that international instruments that establish criteria to set the scope of compensation, be they treaties ${ }^{138}$ or guides, ${ }^{139}$ result in rules on compensation that have

132 The World Bank Guide (n 97), establishes (IV.8):

Compensation will be deemed to be 'prompt' in normal circumstances if paid without delay. In cases where the State faces exceptional circumstances, as reflected in an arrangement for the use of the resources of the International Monetary Fund or under similar objective circumstances of established foreign exchange stringencies, compensation in the currency designated under Section 7 above may be paid in installments within a period which will be as short as possible and which will not in any case exceed five years from the time of the taking, provided that reasonable, market-related interest applies to the deferred payments in the same currency.

133 The World Bank Guide (n 97) establishes (IV.7): 'Compensation will be deemed 'effective' if it is paid in the currency brought in by the investor where it remains convertible, in another currency designated as freely usable by the International Monetary Fund or in any other currency accepted by the investor'.

134 In AMINOIL (n 70) 1033, para 144, it was established that: 'the determination of appropriate compensation is better carried out by means of an inquiry into all circumstances relevant to the particular case, than through abstract theoretical discussion'.

135 UNGA Resolutions 1803 (1962) and 3171 (1973).

136 UNGA Resolutions 3201 (1974) and 3281 (1974). States have the right '(T)o nationalize, expropriate or transfer ownership of foreign property, in which case appropriate compensation should be paid by the State adopting such measures, taking into account its relevant laws and regulations and all circumstances that the State considers pertinent'.

137 Al Qurashi (n 5) 126-27.

138 Art 13.1 ECT (n 6) states that:

Such compensation shall amount to the fair market value of the investment expropriated at the time immediately before the expropriation or impending expropriation became known in such a way as to affect the value of the investment. Such fair market value shall at the request of the investor be expressed in a freely convertible currency on the basis of the market rate of exchange existing for that currency on the valuation date. Compensation shall also include interest at a commercial rate established on a market basis from the date of expropriation until the date of payment.

Art IV (2) of the Iran-USA Friendship Treaty establishes that 'compensation ... shall represent the full equivalent of the property taken'. 139 The World Bank Guide (n 97) establishes:

3. Compensation will be deemed 'adequate' if it is based on the fair market value of the taken asset as such value is determined immediately before the time at which the taking occurred or the decision to take the asset became publicly known. 4. Determination of the 'fair market value' will be acceptable if conducted according to a method agreed by the State and the foreign investor (hereinafter referred to as the parties) or by a tribunal or another body designated by the parties. 5 . In the absence of a determination on agreed by, or based on the agreement of, the parties, the fair market value will be acceptable if determined by the State according to reasonable criteria related to the market value of the investment, i.e., in an amount that a willing buyer would normally pay to a willing seller after taking into account the nature of the investment, the circumstances in which it would operate in the future and its specific characteristics, including the period in which it has been in existence, the proportion of tangible assets in the total investment and other relevant factors pertinent to the specific circumstances of each case. 6 . Without implying the exclusive validity of a single standard for the fairness by which compensation is to be determined and as an illustration of the reasonable determination by a State of the market value of the investment under Section 5 above, such determination will be deemed reasonable if conducted as follows: (i) for a going concern with a proven record of profitability, on the basis of the discounted cash flow value; (ii) for an 
gained international customary character from the PIL perspective. In any case, these international instruments, as much as the arbitral awards, start from the market value of the expropriated assets at the time of the expropriation, emphasizing the importance of determining the moment at which it took place, in conformity with what was decided in the Chorzow case (1928). ${ }^{140}$ Hence, it seems clear that the determination of the market value of the expropriated assets constitutes an essential element in the process of quantifying the compensation amount for which, beyond the valuation of assets, in practice, arbitrators take into consideration their present capacity to generate benefits in the future. ${ }^{141}$ From this perspective, it is possible to consider, at least, the ascertaining of certain lex petrolea parameters.

However, the arbitral jurisprudence is not uniform in the way in which the market value is calculated, as different methods are used, ${ }^{142}$ or in the determination of compensation. In this regard, a number of arbitral awards have decided that it is adequate to compensate for the full value of the property (full compensation), ${ }^{143}$ including in certain cases lost profits. In other cases, once the full valuation is done, the investors' reasonable expectations and the affected public interests of the situation at the time of the dispute, are taken into consideration in a way that, in calculating the amount of the compensation, it is possible to discount the market value as long as this does not lead to the unjust enrichment of the expropriating State. The compensation adequacy allows for this flexibility to reach the amount considered to be equitable.

In any case, when there are expropriation situations, the common practice is to try to reach an agreement through renegotiation with the host State before resorting to arbitral or judicial procedures. This negotiation is a requirement that can be found in bilateral investment treaties ${ }^{144}$ and even in some contracts. ${ }^{145}$ All this is done without disregarding that the international instruments such as the UN Resolutions or the ECT, recognize the

enterprise which, not being a proven going concern, demonstrates lack of profitability, on the basis of the liquidation value; (iii) for other assets, on the basis of (a) the replacement value or (b) the book value in case such value has been recently assessed or has been determined as of the date of the taking and can therefore be deemed to represent a reasonable replacement value.

The rule continues establishing the definition of each of the concepts used.

140 The PCIJ sentence in the Chorzow case (Germany $v$ Poland), 1928, A Series, no 17, at 47, established that the expropriation compensations has to be the corresponding amount of the good at the time the owner was deprived of them plus interest until the payment day.

141 As an example, in AMOCO (n 40), and in Phillips Petroleum (n 111) with different methods.

142 The discounted cash flow (DCF) method considers what goods may render during their productive life deducing, on the one hand, the costs that it will take producing it and, on the other, a percentage that represents the present value of the future expected benefits. The underlying asset valuation (UAV) uses the depreciated value and then adds an 'intangible good' value based on the rents that reflect historic gains, that is multiplied by a factor that takes into consideration the investors legitimate expectations. In certain cases, the arbiters introduce equity considerations that, as pointed out by E Lauterpacht, 'Issues of Compensation and Nationality in the Taking of Energy Investments' (1990) 8 J En \& Nat Res L at 246-49, can only be done at the time of fixing the compensation amount.

143 Some cases affecting Iran and USA, in which the bilateral friendship treaty has to be taken into consideration, and other ICSID cases. M Mendelson, 'Compensation for Expropriation: The Case Law' (1985) 79 AJIL 414-18. On this issue see also B Sabahi, 'The Calculation of Damages in International Investment Law' in P Kahn and TW Wäelde (eds), New Aspects of International Investment Law (Academy of International Law, Martninus Nijhoff 2007) 553-96.

144 As an example art 11 of the Bolivia-Spain BIT states: ' 1 .... To the extent possible, parties to the dispute will try to solve their differences through an amicable agreement. 2 . If the dispute could not be resolved this way within six months counted from the notification date... the dispute could be submitted...'.

145 For example, the model clause for the Venezuelan contract states: 
right of companies to present their claim before the expropriating State's courts or independent authorities. ${ }^{146}$

From the above, it is possible to conclude that general (customary) IL comprises certain rules on expropriation. These are compulsory norms binding every subject of IL. Beyond the debates on the applicability of these norms to non-subjects of $\mathrm{IL}^{147}$ as is the case of hydrocarbon companies, and their characterization as general principles of law, these norms have been understood to be necessarily applicable to oil and gas State contracts up to the point that it is possible to affirm that they have become the custom and practice of this sector of business activity. In other words, independently of their origin, they could be said to be integrated in the sector specific lex mercatoria, the lex petrolea. Whatever the lex contractus of a particular State contract is, these imperative rules will have to be applied. A different issue is how the interpretation and application of these rules is implemented, particularly when they require substantive evaluations. In this respect, beyond resorting to the classical IL interpretation criteria, the establishment of a generalized and accepted understanding of the different concepts could be inferred from the practice, ${ }^{148}$ which in this regard is mostly revealed through arbitral awards. ${ }^{149}$

\section{Economic coercion measures}

Economic coercion (sanction) measures are those prohibitions adopted by a Stateunilaterally, or in an international organization context multilaterally, denying or limiting market access for exportation (boycott); and/or establishing importation embargoes; or restraining the possibility of making financial or investment transactions with a particular

\footnotetext{
... Before initiation any dispute, the parties would look in good faith and within the framework of the Hydrocarbons' Law, the possibility to use mechanisms to amicably resolve the differences of any nature that could appear, including the possible request of technical opinions to mutually agreed independent experts. It is understood that any important dispute, including for example those related to the business plan, the work programs, the development plans and related budgets, shall be referred to the chief executives of both parties, who shall meet to endeavor to resolve the differences. In case the dispute is not resolved within sixty days following the meeting held for such purpose, they shall inform the Minister of the relevant details of the dispute.
}

146 Resolution UNGA 1803 (XVII) para 4 establishes that, in cases of nationalization or expropriation, when the compensation issue generates a dispute, internal jurisdictional resources should be exhausted, notwithstanding the parties resort to arbitration or to international adjudication. Also art 13.2 ECT states: 'The Investor affected shall have a right to prompt review, under the law of the Contracting Party making the Expropriation, by a judicial or other competent and independent authority of that Contracting Party, of its case, of the valuation of its Investment, and of the payment of compensation, in accordance with the principles set out in paragraph (1)'.

147 One of the objectives of this debate is establishing transnational companies' international responsibility for the compliance of essential international norms, as it is reflected in the UN Draft Code of Conduct for transnational corporations, E/C.10/Ac.2/8; E/CN.4/Sub.2/2003/38/Rev.2, 26 August 2003 see also, (1984) 23 ILM 626.

148 That could even lead to the introduction of notions, at least, partially borrowed from municipal legal systems. On the interaction between international and municipal law when institutions of municipal law (ie contracts, property) are recognized but not substantively regulated in the international realm see Sasson (n 14) 195-208 (particularly in what concerns investment arbitration), arguing for a renvoi to municipal law in order to fill the substance of the concepts and, moreover, to avoid that the settlement of disputes under investment treaties risk divorcing from the rule of law.

149 Beyond the debates — and abundant literature — on the existence of arbitral jurisprudence, particularly in the investment field, practice shows that, although not uniform, arbitral awards provide a consistent case load. Some have even argued that it 'may be considered an expression of customary law'. I Alvik, Contracting with Sovereignty. State Contracts and International Arbitration (Hart Publishing 2010) 6-7. In this regard, the position of the arbitral courts tends to be as reflected in the Burlington Decision on Jurisdiction (n 109): the court is not obliged to follow previous arbitral awards; at the same time (except for arbiter Stern) they consider it important to pay adequate attention to those awards, seeking to contribute to the harmonious development of investment law. At the time of writing, the case is still pending. 
State or with those persons operating under its jurisdiction. In the end, these measures are articulated by forbidding private operators to get involved in commercial activities and, although in principle they are addressed to the national industries, in certain cases their scope is extended to operators acting beyond the coercing State jurisdiction. ${ }^{150}$

The adoption of these measures and, sometimes, the mere possibility of their adoption, ${ }^{151}$ have important repercussions for the hydrocarbon sector with regards to economic coercion. For the sanctioned State, the possibilities of receiving foreign capital and technology, and of exporting oil, disappear. The sanctioning States lose important opportunities to have access to natural resources because, considering the time needed to find and exploit them, it is predictable that others will enjoy the possibility of doing so ${ }^{152}$ and, once the sanctions are withdrawn, it may be difficult to regain access by re-establishing commercial relations with the sanctioned State.

From the IL perspective, international organizations such as the UN, in the international political conflicts context, and the WTO, in the dispute resolution process on the application of the agreements administered by the organization, are expressly authorized to adopt economic coercion measures. Some of these measures, which can be multilateral and enjoy international legitimacy, have had repercussions on oil and gas operations. In particular, the UN Security Council has adopted a number of resolutions at different times sanctioning, among others, Angola, Haiti, Libya, Rhodesia, Ivory Coast, Iraq and Iran. ${ }^{153}$ At the time of writing, it has been impossible to reach an agreement in the recent Syrian case. ${ }^{154}$

${ }^{150}$ An absolutely distinct issue is the market power that certain companies may have. As pointed by KW Blinn, C Duval H Le Leuch and A Pertuzio 'International Petroleum Exploration \& Exploitation Agreements' Legal, Economic and Policy Aspects (Barrows, New York, 1986) at 48, the use of their market power can lead to a situation equivalent to an oil embargo. That was the case with Iranian oil in 1951, when companies reacted to the nationalization and the creation of the National Iranian Oil Company in Iran, by concerting their commercial practices.

${ }^{151}$ For example, it is possible to remember the difficulties Iran experienced to finance the exploration and exploitation of its resources when it was unclear whether UN would impose sanctions as a result of the development of its nuclear industry. The situation leaded to talk about de facto sanctions, N Bozorgmeh, 'Iran Admits Oil Projects Suffering', FT, 20 December 2006. A more recent and different example—related to a unilateral measure—can be seen in Total's strategy of stopping its exports from Syria before the European Union (EU) had adopted the embargo. S Pfeifer and D Blair, 'Total Charts Risky Path in Hunt for Oil', FT, 12 October 2011

152 For example, in 2006, the Indian companies ONGC and Reliance Industries, managed to gain access to exploration blocks in Iraq (in joint venture with Sonatrach). A Yee, 'India's Oil Companies Plan Iraqi Venture', FT, 26 December 2006.

153 The UN Resolution 864 (1993), of 15th September, imposed the weapons and oil embargo to the Union for Angola Total Independence, whose effects were terminated by Resolution 1448 (2002) of 9th December; Resolution 841 (1993), of the 16th June imposed an weapons and oil embargo on Haiti that, after a temporary suspension, was adopted again and finally terminated by Resolution 917 (1994), of the 29th September; Resolution 883 (1993) of 11th November, prohibited providing oil refining and transport equipment to Libya, and was terminated by Resolution 1506 (2003) of the 12th September; Resolution 232 (1966) of 16th December, imposed sanctions on goods and oil to Rhodesia that were terminated by Resolution 460 (1979) of 21st December; Resolution 1132 (1997) of 8th October, imposed an oil embargo on the Ivory Coast, that was terminated by Resolution 1156 (1998), of 16th March; and Resolution 661 (1990) of 6th August, imposed a total commercial embargo on Iraq, that Resolution 1483 (2003) of 22nd May, was limited to weapons. In this last case, considering the difficulties the country was going through, it was offered the possibility of exporting oil in limited amounts and with certain conditions under the 'food for oil' program. Iran was also sanctioned through Resolution 1737 (2006).

154 In the Syrian case, the UN Security Council could not take a decision demanding an immediate end to the violence and expressing that it would consider 'options', which could include unspecified measures (maybe economic sanctions) after 30 days-due to the Russia and China veto of any decision that would put international pressure on Syrian Government. C Clover, 'Russia Sparks Outrage Over Syria Veto at UN', FT, October 2011. 
As to economic coercion measures unilaterally adopted by a State, it has to be noted that, although IL does not prohibit them, ${ }^{155}$ their compatibility with international agreements, such as those administered by the WTO, ${ }^{156}$ can be questioned. Moreover, when these unilateral measures extend their application to persons not subject to the national jurisdiction, they tend to provoke the reaction of other States, whose economic sectors may be prejudiced, through countermeasures. The USA has been one of the States that has resorted more frequently to economic coercion measures. The D'Amato-Kennedy Act against Iran and Libya ${ }^{157}$ has had special impact in the oil sector. The EU reacted against this Act, adopting Regulation $2271 / 96^{158}$ and, in fact, in Iran's case the sanctions were barely applied. Continuing in the oil sector, the EU adopted economic coercion measures against Syria due to the government's violent repression of the population demanding democratic reforms. ${ }^{159}$ Regarding hydrocarbons, the measures imply the prohibition of imports that, within the EU, where they are significant and have a major effect on the Syrian economy, enjoyed a transition period ending in November 2011. ${ }^{160}$ Moreover, they allow ' . . restrictions on the admission to the Union, and the freezing of funds and economic resources of certain persons and entities ...', including Syrian oil companies. Although under these circumstances European companies-Shell and Total—could remain in the area, Shell decided to leave. ${ }^{161}$ In the Syrian case, the United States has followed a similar approach.

155 There is no IL rule that prohibits regulating non-State connected activities. In any case, for IL the mere existence of a norm is not on itself illicit; what is relevant is that its application entails a violation of an international norm.

156 For example, art XI of GATT prohibits quantitative restrictions or measures having equivalent effect, which could be justified on the basis of national defence (art XXI). C Otero García-Castrillón, 'La ley de libertad y solidaridad democrática con Cuba (Libertad Act) en el marco de la regulación del comercio internacional' (1997) XLIX REDI 372-77.

157 Iran-Libya Sanctions Act (ILSA), adopted by the US Congress the 8th August 1996, punishes companies that, irrespective of their nationality, make investments over a certain amount in the energy sector in those countries or violate the UN commercial ban, forbidding them to export or buy goods in the United States. In September 2004 the United States removed certain sanctions to Libya and in 2006 there were already oil companies working in the country. The law was extended for five years in August 2001, and again (fully terminating its application to Libya) for a period that expired on 31 December 2011. In 2010, the law has been modified (Comprehensive Iran Sanctions, Accountability, and Divestment Act of 2010), including changes in the limits of the allowed investments in the development of oil resources. No firms have been sanctioned under the Iran Sanctions Act.

158 Council Regulation 2271/96, of 22 November 1996, protecting against the effects of the extra-territorial application of legislation adopted by a third country, and actions based thereon or resulting [1996] OJ L309/1. Art 4 established that '( $\mathrm{n}$ )o judgment of a court or tribunal and no decision of an administrative authority located outside the Community giving effect, directly or indirectly, to the laws specified in the Annex or to actions based thereon or resulting there from, shall be recognized or be enforceable in any manner; and art 5 forces not to respect, directly or through a subsidiary or intermediary person, actively or by a deliberate omission, any measure included, in the Regulation Annex (or from actions based thereon or resulting therefrom).

159 Council Decision 2011/273/CFSP of 9 May 2011, concerning restrictive measures against Syria [2011] OJ L121/11, and Council Regulation 442/2011, of 9 May 2011, concerning restrictive measures in view of the situation in Syria [2011] OJ L121/1, and its implementing Regulation 1244/2011, [2011] OJ L319/8. Some European countries have reacted abandoning the country.

160 This was the only way to overcome Italian opposition, which was trying to delay the adoption of the measure until the time when oil demand was reduced in the local refineries due to maintenance works. J Blas 'Embargo on Syrian Crude Could Have Impact on Prices', FT, 1 September 2011. Since this embargo has serious consequences, Syria looked for new customers; A Fifield, 'Syria to Look East for Oil Markets', FT, 26 September 2011. The difficulty in finding new customers and the pressure the potential ones exercise to get better prices, forced Syria to order reducing production. J Blas, 'EU Ban Forces Syria to Cut Oil Production', FT, 26 September 2011. See Council Regulations 878/2011, of 2 September [2011] OJ L228/1, and 950/2011, of 23 September 2011, amending Regulation 442/2011 concerning restrictive measures in view of the situation in Syria [2011] OJ L247/3.

161 J Blas, 'Shell to Quit Syria', FT, 2 December 2011. 
Although it is doubtful that multilateral economic coercion measures directly oblige oil companies to comply, in that they are not IL subjects, it has been argued that when they are designed as erga omnes obligations, they can have a direct effect even on nationals and companies of non-UN States or of States that have not adopted the measures in their national law system. ${ }^{162}$ This would be in line with the objective of establishing the international responsibility of transnational companies for compliance with essential international norms and, therefore, relates to the ongoing debates on the new subjects of IL as reflected in the UN Code of Conduct for Transnational Corporations. ${ }^{163}$

In any case, it is evident that companies related to the States' adopting economic coercion measures, be it on the basis of their establishment or of their business activity, have to comply with them independently of what the lex contractus may be. ${ }^{164}$ Considering the subsequent economic harm, companies tend to support any initiative and make informal efforts to change the measures or to somehow influence their application. Beyond that, they can only prepare for the day when the sanctions will be removed and trust that, by then, there will still be possibilities to get involved in business in the affected market. In the interim, other companies not compelled to respect the economic coercion measure may have exploited the available business opportunities. ${ }^{165}$

Eventually, some companies get involved in operations infringing economic sanctions. In cases of unilateral measures, despite reducing the business activity to a certain extent, the affected companies can avoid them through the backing of the countermeasures adopted in the companies' countries of origin; and in certain cases, with a limited application of the measure by the sanctioning State. ${ }^{166}$ Moreover, in cases of unilateral as much as multilateral measures, it is possible to observe 'hidden' non-compliance through the direct involvement in the business operations of subsidiaries located in the sanctioned State, especially if they have local partners or act under the direction of the host State. ${ }^{167}$ In these circumstances, in case they were prosecuted, they would have reasons which may

162 T Waelde, 'Managing the Risk of Sanctions in the Global Oil \& Gas Industry: Corporate Response Under Political, Legal and Commercial Pressures' (1997) 2 CEPMLP Internet J 9, <http://www.dundee.ac.uk/cepmlp/journal/html/volume2.html>. On the relationship of the UN sanctions and their application through municipal law, see J Matringe, 'Problèmes et teqchniques de mise en oubre des sanctions économicques de l'organisation des Nations Unies en droit interne', in L Picchio Forlati and LA Sicilianos (eds), Economic Sanctions in International Law (Kluwer Law International 2004) 637-81.

163 See n 147.

164 FJ Garcimartín Alférez, Contratación internacional y medidas de coerción económica (Beramar 1993) 48-50 and 122-36. See also A Cissé, 'Les effets des sanctions économiques de l'Organisation des Nations Unies sur les contrats' L Picchio Forlati and LA Sicilianos (eds), Economic Sanctions in International Law (Kluwer Law International 2004) at 683-715, and B Cortese, 'International Economic Sanctions as a Component of Public Policy for Conflict of Laws Purposes', in L Picchio Forlati and LA Sicilianos (eds), Economic Sanctions in International Law (Kluwer Law International 2004) 724-33. On the application by arbitrators of economic coercion measures see 741-42.

165 For example, in 2006, Inpex (Japan) reduced its participation in the exploitation of the Azadegan field (Iran) from 75 to 10 per cent fearing the consequences of the USA sanctions - a country with which it has tight political relations-; as a result, Chinese companies were entering in the country, G Smyth, 'Japan Loses Out on Massive Iranian Oil Field amid Fears of US Sanctions', FT, 27 October 2006

166 See n 158. Despite US ILSA sanctions, Total (France), Royal Dutch Shell (British-Dutch), Statoil (Norway), Repsol (Spain), ENI (Italy), OMV (Austria), Petrobras (Brazil) and CNPC and Sinopec (China), continued working in Iran. C Hoyos, 'Total Defies US with Vow to Continue Iran Oil Drive', FT, 8 September 2006. In the Iraq case, American and British firms won early lucrative contracts in oil and gas, including ExxonMobil's and Royal Dutch Shell's bid to develop Iraq's oil resources, whilst other business sectors received no investments from these sanctioning countries. I Saigol, 'Spoils of Iraq War Evade US and UK', FT 15 December 2011.

167 That was the case in Rhodesia with BP, SHELL and MOBIL subsidiaries. Waelde (n 162) 26. 
help in trying to justify their actions. Nevertheless, in the hydrocarbon industry, non-compliance with the economic coercion measures implies, beyond the legal and economic risks that could derive from the application of internal sanctions, the risk of civil society censure, particularly when sanctions have been adopted by the UN.

On the other hand, the economic coercion measure mandate can lead to the non-compliance with a contract. Though the non-compliant party could be exonerated from its responsibility on the basis of force majeure, ${ }^{168}$ the express provision of this eventuality in the contract would offer more guarantees, for example, by allowing that in these circumstances the affected companies could abandon the contract without penalty, or by establishing the company's lack of financial responsibility for the damages caused to its partners or clients in cases where the sanctions force the abandonment of non-compliance with the contract. ${ }^{169}$ A different issue would be the possibility for a private company to claim the non-contractual liability of the sanctioning State for the damages suffered as a consequence of the compliance with the measure. ${ }^{170}$

Hence, whatever the lex contractus is, economic coercion measures will be applicable when the companies involved in the contractual relationship are personally or commercially related to the sanctioning State in unilateral measures, or the international organization in multilateral measures. In the latter case, the debate remains on the imperative character and direct applicability to private companies of the economic coercion measures adopted by the UN.

\section{Conclusion}

The legal regime applicable to oil and gas international contracts is usually determined by a number of normative instruments that, in the vast majority of cases, operate in a simultaneous and coordinated way. From a private IL perspective, beyond parties making use of their autonomous will to establish their respective substantive compromises resorting to, and to a large extent establishing, the commercial customs and uses of the sector (lex petrolea stricto sensu), the contracts often contain conflict of laws clauses.

Conflict of law clauses tend to opt for a combination of legal rules that, in the majority of the cases, include host State law and IL principles and rules. Even when these last ones are not expressly mentioned, they invariably appear generally to be associated with the host State legal system. When contracts do not include choice of law clauses, conflict of laws norms will lead to a similar solution. In any case, IL principles constitute the basis on

168 However, the impediments derived from public prohibitions have not always been qualified as force majeure. Vid. on Rolimpex case KH Böeckstiegel, 'Hardship, Force Majeure and Special Risk Clauses in International Clauses' in N Horn (ed), Adaptation and Renegotiation of Contracts in International Trade and Finance. Studies in Transnational Economic Law, vol. 3 (Kluwer 1985) $156-168$.

169 Waelde (n 163) 15.

${ }^{170}$ For example, a Greek company claimed the EU non-contractual liability for the adoption of Regulation 2340/90, on the Iraq and Kuwait commercial embargo. Ellini Viomichania v EC Council and Commission, T-220/96, of 24 April 2002. Considering the requirements for EU non-contractual liability (EU institutions illicit behaviour, the reality of the harm, and the causal relationship between them), the court established that causal effect one was not fulfilled because the refusal of payment was based on UN Council Resolutions (establishing payment freezing sanctions) and not on the EU Regulation. See paras 39 and 42 . 
which the sector-specific lex mercatoria sits and, therefore, they could be claimed to have become part of it. Even without being mentioned in the determination of the applicable law, the lex petrolea is used anyway, particularly within arbitration, as a means for interpreting and completing contract terms.

In addition to the unavoidable application of the lex contractus imperative norms, the application of IL is compulsory when it comes to issues like expropriation. Moreover, despite the difficulties, economic coercion measures adopted in multilateral forums have been suggested to have an imperative character. However, as to this kind of measure, the only certainty is that its application will be imposed, whatever the lex contractus is, on companies personally or commercially related to the sanctioning States. 